\title{
EL ARBITRAJE DOMÉstico COLOMBIANO A LA SOMBRA DE LA AMIGABLE COMPOSICIÓN COMO MECANISMO QUE PRIVILEGIA LA AUTONOMía de LA VOLUNTAD*
}

\section{COLOMBIAN DOMESTIC ARBITRATION IN THE SHADOW OF "AMIGABLE COMPOSICIÓN", AN ADR THAT FAVORS PARTY AUTONOMY}

\author{
Pablo Rey-Vallejo** \\ Fecha de recepción: 7 de junio de 2016 \\ Fecha de aceptación: 20 de septiembre de 2016 \\ Disponible en linea: 30 de noviembre de 2016
}

\section{Para citar este artículo/To cite this article}

\begin{abstract}
Rey-Vallejo, Pablo, El arbitraje doméstico colombiano a la sombra de la amigable composición como mecanismo que privilegia la autonomía de la voluntad, 133 Vniversitas, 227-270 (2016). http://dx.doi.org/10.11144/ Javeriana.vj133.adcs
\end{abstract}

doi:10.11144/Javeriana.vj133.adcs

* Este artículo de reflexión se enmarca en la investigación adelantada por el autor en el programa de doctorado en ciencias jurídicas, Pontificia Universidad Javeriana, Bogotá. El autor forma parte del grupo de investigación en Derecho Económico de esta Universidad.

** Abogado, Universidad de los Andes. LLM International Business Law, London School of Economics and Political Science, LSE. Este artículo forma parte integral del documento de tesis doctoral. Contacto: alfr-rey@uniandes.edu.co 


\section{RESUMEN}

El presente artículo es una reflexión derivada de una investigación y aborda la problemática de las restricciones impuestas a la autonomía privada para configurar el procedimiento arbitral, derivadas de la fórmula de constitucionalización de esta figura. Para ello, realiza un ejercicio comparativo sobre la amigable composición como un ejemplo de mecanismo de solución de controversias cuyo carácter contractual, reconocido únicamente en el plano legal, privilegia en mayor medida la autonomía de la voluntad en la determinación de su trámite. Así, para demostrar que el constituyente y el legislador colombiano habrían podido privilegiar en mayor medida la autonomía de la voluntad en el arbitraje, se analizan las similitudes de este mecanismo con la amigable composición. De esta manera, mediante una investigación sobre las raíces, la evolución normativa y jurisprudencial de la amigable composición en Colombia y en el derecho comparado, se identifica el porqué de las grandes diferencias prácticas en la forma de llevar a cabo estos dos trámites.

Palabras clave: Mecanismos alternativos de solución de conflictos; arbitraje; arbitraje doméstico; amigable composición; autonomía de la voluntad; constitucionalización del derecho privado; constitucionalización del arbitraje 


\section{ABSTRACT}

In this paper, the author analyzes the restrictions imposed on party autonomy to set the arbitration procedure, derived from Constitutional Law inter alia. He does so, through a comparative exercise that deals with the case of amigable composición as an example of ADR whose contractual nature favors party autonomy. In order to demonstrate that the constituent and the Colombian legislator could have further favor party autonomy in arbitration, the author analyses the similarities between these two mechanisms. Thus, through an investigation on the roots, regulation and jurisprudential evolution of amigable composición in Colombia and in comparative law, he identifies why there are so many differences in the practice of these proceedings.

Keywords: ADRs; arbitration; domestic arbitration; amiable compositeur; party autonomy; constitutionalization of private law; constitutionalization of arbitration

\section{SUMARIO}

INTRODUCCIÓN.- I. El ARBitRAJE EN EL ENTORNO CONSTITUCIONAL COLOMBIANO.- $A$. El arbitraje y los métodos alternativos de solución de conflictos (MASC).- B. Efectos prácticos de la constitucionalización del arbitraje en Colombia.- II. La Amigable Composición en el DeReCho Colombiano.- $A$. La amigable composición: breve reseña sobre sus orígenes e incorporación al derecho colombiano.- 1 . Antecedentes históricos.- 2. El caso colombiano.- 3. Similitudes en el derecho comparado.- B. Discusiones alrededor de la naturaleza autocompositivalheterocompositiva de la amigable composición.- 1. El mandato y la representación como elementos que dan origen a la autocomposición.- 2. Aproximación funcional de la amigable composición a otros mecanismos heterocompositivos como el arbitraje.- III. LA AUTONOMÍA DE LA VOLUNTAD EN EL ÁMBITO DE LOS MECANISMOS ALTERNATIVOS DE SOLUCIÓN DE CONFLICTOS EN GENERAL Y LA AMIGABLE COMPOSición EN PARTICULAR.- $A$. Autonomía de la voluntad, libertad y mecanismos alternativos de solución de conflictos.- B. Autonomía de la voluntad y la amigable composición.- 1. Perspectiva del ordenamiento legal vigente.- 2 . Perspectiva jurisprudencial.- ConClusiones.- Bibliografía. 


\section{INTRODUCCIÓN}

En este artículo realizaremos un estudio de la institución de la amigable composición en el derecho colombiano, para demostrar que se trata de un mecanismo de composición o adjudicación en el que, a diferencia del arbitraje, su autonomía respecto de otras reglas del derecho constitucional y procesal resulta más ampliamente asegurada. En el mismo sentido, resaltaremos que el amplio margen de operatividad de la autonomía de la voluntad le caracteriza como una figura verdaderamente flexible en la que se garantizan los postulados de la libertad contractual dentro de unos límites menos estrictos y rigurosos, que los que la ley y la jurisprudencia han impuesto al mecanismo arbitral.

Para tales efectos, hemos considerado que si bien el arbitraje y la amigable composición son mecanismos de naturaleza diversa, los orígenes y las raíces de esta última están más ligados al arbitraje de lo que parece a simple vista. Adicionalmente, a pesar de que en el derecho colombiano actual la amigable composición resulta ser un contrato complejo que involucra el contrato de mandato entre los suscriptores y el amigable componedor, su finalidad adjudicativa de derechos y obligaciones, y la posibilidad de que se traten aspectos de responsabilidad, permiten estrechar los lazos entre una y otra figura.

En tal sentido, es admisible entender que el constituyente podría haber otorgado un tratamiento similar al arbitraje y a la amigable composición en el texto superior, bien sea mediante su asimilación como mecanismos jurisdiccionales, como sucede con el arbitraje, o incluso optando por no reconocerlas como instituciones de raigambre constitucional, como en el caso de la amigable composición.

En este orden de ideas, en este texto, nos enfocaremos en el análisis y el estudio de la normatividad, las reglamentaciones y la jurisprudencia desatadas alrededor de la amigable composición, previa exposición breve y somera del panorama arbitral, que no será objeto de profundización en este escrito ${ }^{1}$. La hipótesis planteada en

1 Para tales efectos, revisar: Pablo Rey-Vallejo, La autonomía del arbitraje doméstico desde la perspectiva constitucional en Colombia y puntuales análisis de derecho comparado latinoamericano, 34 Revista de Derecho Público, Universidad de los Andes, 1-37 (2015). Disponible en: https://derechopublico.uniandes.edu.co/components/com_revista/archivos/derechopub/ pub496.pdf 
esta investigación consiste en demostrar que la "desconstitucionalización" de los mecanismos alternativos de solución de conflictos de carácter adjudicativo fomenta en mayor medida su autonomía respecto de otras ramas del derecho y le imprime mayor preponderancia al precepto de libertad contractual, en especial cuando la "fórmula" de constitucionalización implica el reconocimiento de la figura en cuestión como un mecanismo de carácter jurisdiccional.

\section{EL ARBITRAJE EN EL ENTORNO CONSTITUCIONAL COLOMBIANO}

La decisión de incorporar el arbitraje como una figura de rango constitucional en la Carta Política de $1991^{2}$ dio lugar a un extenso desarrollo jurisprudencial en sede del máximo tribunal de la materia tanto en el ámbito de las acciones de amparo o tutela, por ser un mecanismo de protección de derechos fundamentales, como en lo relativo a las acciones de constitucionalidad que velan por la conformidad del ordenamiento legal con el espectro de la Carta Política.

\section{A. El arbitraje y los métodos alternativos de solución de conflictos (MASC)}

En nuestro país, el arbitraje está inscrito en los llamados métodos alternativos de solución de conflictos, entre los cuales solo la conciliación y el arbitraje tienen reconocimiento constitucional explícito, específicamente en el artículo 116 superior. Por otro lado, figuras como la transacción, la amigable composición y la mediación han sido desarrolladas en el plano legal o, en el caso de esta última, en el meramente convencional.

Para el tribunal constitucional, los métodos alternativos pertenecen a una categoría de justicia "informal" que no tiene como finalidad sustituir la justicia estatal "formal", sino complementarla, por lo que considera necesario que el legislador desarrolle y propicie

2 Colombia, Constitución Política, promulgada el 7 de julio de 1991, versión corregida, 116 Gaceta Constitucional, 20 de julio de 1991, artículo 116. Disponible en: http://www.secretariasenado. gov.co/senado/basedoc/constitucion_politica_1991.html 
políticas de Estado tendientes a vincular a la sociedad civil en la construcción de estos espacios comunes ${ }^{3}$.

Adicionalmente, el alto tribunal destaca la poca efectividad de la justicia "formal" cuando el Estado no le provee a esta los recursos suficientes que permitan su funcionamiento adecuado. Igualmente, que la complejidad de algunos procedimientos y las dificultades que en ocasiones el mismo legislador dispone para el acceso a la administración de justicia obstaculizan a los ciudadanos el goce efectivo de sus derechos. No obstante, para la Corte, los mecanismos alternativos de resolución de conflictos no constituyen una expresión de desconfianza frente a la justicia estatal sino que representan una opción con procedimientos menos formales para resolver las disputas, en especial aquellos de carácter autocompositivo ${ }^{4}$.

En resumen, la jurisprudencia constitucional ha señalado que los mecanismos alternativos de resolución de conflictos alcanzan los siguientes objetivos: (i) buscan hacer efectivo uno de los fines constitucionales como el de la convivencia pacífica; (ii) permiten la participación directa de los interesados en la resolución de sus conflictos; (iii) son otra forma de hacer efectivo el derecho de acceso a la administración de justicia, y (iv) son un buen mecanismo para lograr la descongestión judicial ${ }^{5}$.

Por otro lado, además de reiterar los conceptos sobre la forma de clasificación de los mecanismos y señalar sus bondades, la jurisprudencia de la Corte ha vinculado inescindiblemente estas figuras con el derecho fundamental de acceso a la justicia que, a su vez, forma parte del núcleo esencial del derecho al debido proceso. En tal sentido, resulta imperativo para la alta corporación que estos mecanismos cuenten con "procedimientos idóneos y efectivos para la determinación legal de derechos y obligaciones, que las controversias planteadas sean resueltas dentro de un término prudencial y

3 Colombia, Corte Constitucional, Sentencia C-893-01, 22 de agosto de 2001, magistrada ponente Clara Inés Vargas-Hernández, Consideraciones y fundamentos de la Corte, 5. Disponible en: http://www.corteconstitucional.gov.co/relatoria/2001/c-893-01.htm

4 Colombia, Corte Constitucional, Sentencia C-1195-01, 15 de noviembre de 2001, magistrados ponentes Manuel José Cepeda-Espinosa y Marco Gerardo Monroy-Cabra, Consideraciones y fundamentos de la Corte, 4.3. Disponible en: http://www.corteconstitucional.gov.co/ relatoria/2001/c-1195-01.htm

5 Colombia, Corte Constitucional, Sentencia C-222-13, 17 de abril de 2013, magistrada ponente María Victoria Calle-Correa, Consideraciones y fundamentos de la Corte, 4.2. Disponible en: http://www.corteconstitucional.gov.co/relatoria/2013/c-222-13.htm 
sin dilaciones injustificadas, que las decisiones sean adoptadas con el pleno respeto del debido proceso, que exista un conjunto amplio y suficiente de mecanismos para el arreglo de controversias, que se prevean mecanismos para facilitar el acceso a la justicia por parte de los pobres, que la oferta de justicia permita el acceso a ella en todo el territorio nacional".

Respecto de la consagración y el desarrollo legal de los mecanismos alternativos consagrados constitucionalmente, la Corte considera que se trata de una situación que puede ocurrir y que al plasmarse en el ordenamiento jurídico deben respetarse, como es evidente, los lineamientos constitucionales. Esta reglamentación de la materia resulta compatible con la Carta Política y además cumple el objetivo de interpretar y desarrollar principios y valores transversales a la Constitución, como la búsqueda de la paz, la convivencia y el orden justo.

Frente al arbitraje en particular, la Corte Constitucional ha desarrollado su jurisprudencia desde una perspectiva eminentemente jurisdiccional, pues la consagración que se hace de este mecanismo en el artículo 116 superior así lo dispone. Estas consideraciones han derivado en un reconocimiento limitado del carácter contractual del arbitraje que circunscriben sus características convencionales a la suscripción del acuerdo de arbitraje, la configuración de algunos aspectos de su procedimiento y a su carácter voluntario, pero otorgándoles un entramado eminentemente procesal al curso del trámite y a las funciones de los árbitros.

\section{B. Efectos prácticos de la constitucionalización del arbitraje en Colombia}

La inclusión del arbitraje como una figura de raigambre constitucional, con el atributo de mecanismo de carácter jurisdiccional, determinó que la jurisprudencia a su alrededor fuera unívoca en el sentido de asimilar la función arbitral a la labor desempeñada por los jueces de la República con las respectivas atribuciones y consecuencias derivadas de sus actuaciones.

6 Colombia, Corte Constitucional, Sentencia C-222-13, 17 de abril de 2013, magistrada ponente María Victoria Calle-Correa, Consideraciones y fundamentos de la Corte, 4.1. Disponible en: http://www.corteconstitucional.gov.co/relatoria/2013/c-222-13.htm 
Así, las decisiones tomadas en el ámbito de la justicia arbitral nacional son susceptibles de control jurisdiccional por vía de acciones de tutela en las mismas condiciones y circunstancias que proceden ante los actos de jueces y magistrados. Esta posibilidad de que los estamentos judiciales intervengan en el funcionamiento de los tribunales arbitrales es considerada como una pérdida de "autonomía" del arbitraje, en el sentido de que se trata de recursos y mecanismos que, desde una perspectiva contractual de la figura, son ajenos a sus propias regulaciones?

En efecto, la autonomía del arbitraje doméstico en Colombia no solo se ha visto afectada con ocasión de la fórmula de consagración constitucional que permitió el control judicial de las decisiones arbitrales por vías diferentes a recursos como el de anulación, sino también por cuenta de que el carácter jurisdiccional del arbitraje incidió en que su práctica se soporte en la aplicación de innumerables normativas del Estatuto Procesal $\mathrm{Civil}^{8}$ en temas como el contenido de la demanda, la "integración de la litis", las notificaciones, la práctica de pruebas, etc.

Ahora bien, es claro que las diversas fórmulas de consagración constitucional del arbitraje, como mecanismo jurisdiccional o

7 En tal sentido, Fernando Mantilla-Serrano señala: "La consagración del arbitraje en un cuerpo autónomo reconoce entonces la 'especificidad' del arbitraje con respecto a la justicia estatal y a los demás métodos alternativos de resolución de controversias. Esas leyes, las más de las veces, tratan de manera exclusiva sobre el arbitraje y, al hacerlo, excluyen cualquier otro tipo de regulación como aplicable al mismo". A lo que agrega: "El segundo aspecto en que se manifiesta la autonomía material del arbitraje radica en el hecho de que las regulaciones modernas sobre arbitraje constituyen lo que podría calificarse como un 'universo cerrado'. En esos cuerpos (por su mayor parte cuerpos legislativos), todas las disposiciones versan sobre arbitraje y en ellos están todas las disposiciones que sobre él tratan. Constituyen así un 'todo' exclusivo en cuanto se centran de manera específica en el arbitraje y lo regulan de manera exhaustiva. (...) Como se mencionaba, el objeto de las leyes de arbitraje modernas abarca todos los aspectos del arbitraje excluyendo la aplicación a las materias de cualquier otra ley, excepción hecha, como no podría ser de otra manera, de las disposiciones procesales que rigen los procedimientos de auxilio judicial en el arbitraje. Y esta es otra consecuencia de la autonomía material de la regulación del arbitraje. No se requiere la aplicación concomitante de otras leyes. Si la ley de arbitraje es aplicable, de manera casi automática las otras leyes de tipo procesal dejan de serlo y la intervención judicial se convierte en excepcional y solo autorizada en aquellas cuestiones previstas por esa ley, dando así origen al verdadero papel del juez en materia arbitral, sabiamente denominado por los suizos como 'juez de apoyo' (juge d'appui)". Fernando Mantilla-Serrano, La autonomía del derecho del arbitraje internacional: ¿hacia un arbitraje realmente autónomo?, en Arbitraje internacional - Tensiones actuales, 207-242, 210 (Fernando Mantilla-Serrano, ed., Legis, Bogotá, 2007).

8 Colombia, Ley 1564 de 2012, por medio de la cual se expide el Código General del Proceso y se dictan otras disposiciones, 48.489 Diario Oficial, 12 de julio de 2012. Disponible en: http:// www.secretariasenado.gov.co/senado/basedoc/ley_1564_2012.html 
como derecho fundamental, como se reconoce en otros países de Latinoamérica, constituyen un precedente suficiente para admitir la intervención del juez constitucional, bien sea mediante acciones de constitucionalidad sobre las disposiciones que lo regulan o mediante acciones de protección constitucional de derechos fundamentales. Por lo anterior, el debate en favor o en contra de la constitucionalización del arbitraje no se debe agotar en la consagración misma del mecanismo en el texto superior sino que debe trascender al análisis del papel del juez constitucional en el que radicará que se garantice o no la mayor autonomía de este mecanismo de solución de controversias.

La discusión en torno a la autonomía del arbitraje doméstico tiene amplias repercusiones en términos del respeto a su esencia contractual y, por ende, de la admisibilidad de una mayor o menor expresión de la autonomía de la voluntad. En efecto, la procedencia de mecanismos de protección y recursos ajenos a la esencia del trámite arbitral, así como su coexistencia con estatutos procesales propios del ámbito judicial, son factores que condicionan el curso del arbitraje y lo enmarcan en esquemas procedimentales más inflexibles.

Por otro lado, también es posible afirmar que la no consagración del arbitraje dentro de una Carta Política no conlleva la imposibilidad de su reconocimiento en el ordenamiento legal ni su adecuado funcionamiento. Así, esta figura tiene plena efectividad en países europeos en los que el fenómeno de la constitucionalización no está presente, como sucedía en Colombia antes de la vigencia de la Constitución de 1991.

\section{LA AMIGABLE COMPOSICIÓN EN EL DERECHO COLOMBIANO}

Si bien la amigable composición es una figura distinta del arbitraje en la legislación colombiana, realizar un análisis sobre la manera en que la ley y la jurisprudencia constitucional la han abordado resulta un ejercicio valioso para identificar las diferencias y similitudes funcionales entre estos dos mecanismos que fueron caracterizados por el constituyente y el legislador como de naturaleza diversa. En este orden de ideas, este ejercicio nos permitirá identificar en qué 
medida un mecanismo alternativo de solución de controversias que i) no está consagrado constitucionalmente y ii) no es de carácter jurisdiccional sino contractual, puede ser o no objeto del establecimiento de reglas jurisprudenciales que deriven en limitaciones a la plena efectividad de la autonomía de la voluntad contractual.

\section{A. La amigable composición: breve reseña sobre sus orígenes e incorporación al derecho colombiano}

Una revisión de la evolución histórica de la amigable composición en el derecho comparado permitirá concluir que cuando el legislador colombiano reglamentó esta figura, se apartó de las definiciones legales y estatutarias de otros ordenamientos jurídicos. Más aún, la evolución de la amigable composición en gran parte de las legislaciones extranjeras no se produjo de manera autónoma y separada al arbitraje, sino que, por el contrario, su historia es inescindible de este otro mecanismo al punto de entender que la amigable composición es en realidad una modalidad de arbitraje.

\section{Antecedentes históricos}

En el derecho romano, la figura del árbitro (arbiter) — a diferencia del juez (iudex) - tuvo especial desarrollo en un ámbito paralelo al derecho procesal oficial, en el que finalmente recaló. Según algunos estudios, una primera recepción del arbiter en el ámbito oficial tuvo lugar en época de los decenviros, siglo V a.C., y posteriormente hacia los siglos III-II a.C. con los arbitrajes de buena fe (arbitria bonce fidei) y se caracterizó por la mayor discrecionalidad que tenía este frente al iudex a la hora de enjuiciar ${ }^{9}$.

Una tercera modalidad incorporada en el ámbito procesal del ius civile fue la del arbitraje compromisario que operaba bajo la premisa del ius honorarium. En lo relativo al modo de operar de esta figura, no aparece que debieran aplicarse las reglas relativas a los juicios ordinarios al punto de que los mismos estaban desproveídos del carácter público, típico de estos ${ }^{10}$.

9 Aparentemente, los más antiguos de estos procedimientos fueron los de fiducia (actio fiducia), dote (actio rei uxorice) y sociedad (actio pro socio).

10 JAVIER PARIcio, Los arbitrajes privados en la Roma Clásica, 42 (Marcial Pons Ediciones Jurídicas y Sociales S.A., Madrid, 2014). 
Así, los escenarios extraprocesales de solución de controversias se vieron fortalecidos en los años de florecimiento del ius gentium para las controversias que involucraban la participación de extranjeros, por medio de mecanismos extralegales fundados en creencias de razón, justicia y equidad ${ }^{11}$.

Posteriormente, el arbitraje comercial fue comúnmente utilizado por los comerciantes en la Edad Media, quizá sobre todo por la falta de gobiernos centralizados y las demandas del comercio interestatal. Un comentarista alemán al comienzo del siglo XX observó, con respecto a las experiencias históricas de ese país, lo siguiente:

Los tribunales arbitrales en todo momento han sido considerados como una necesidad urgente de la comunidad de comerciantes y la legislación siempre les ha concedido un lugar junto a los tribunales ordinarios ${ }^{2}$.

Los países europeos reconocieron el papel del arbitraje en materia comercial y le dieron efecto en diversos estatutos. Todas estas codificaciones legales confirmaron el papel del arbitraje en la solución de controversias comerciales, mientras que les otorgaban a los árbitros diversos grados de libertad respecto de los requisitos de procedimiento y de fondo locales y de control judicial. Estos diversos acontecimientos condujeron al tratamiento del arbitraje en algunos Códigos de Procedimiento Civil que sirvieron de base para los regímenes jurídicos más modernos.

El Código de Procedimiento Civil alemán de $1877^{13}$ incorporó disposiciones que liberaron a los árbitros de la obligación de aplicar las normas legales estrictas y, concurrentemente, de la revisión judicial del fondo de los laudos arbitrales. De conformidad con la obra de GARY B. Born, los redactores del mencionado Código explicaron:

By submitting themselves to arbitration the parties want to escape from the difficulties and complexities arising from the application of the law. They intend that the law as between them should be what the arbitrators, according to their

11 Mario Ricardo Osorio-Hernández, Amigable composición y arbitraje en equidad: pasado presente y futuro de dos engendros colombianos, en Ensayos arbitrales, 13-26 (Cámara de Comercio de Bogotá, Kimpres, Bogotá, 2010).

12 Walter Haeger, Schiedsgerichte für Rechtsstreitigkeiten der Handelswelt, 2 (1910), citado por Klaus Peter Berger \& Catherine Kessedian, Forum Internationale, The New German Arbitration Law in International Perspective: The Draft Convention Proposed by The Hague Conference on Private International Law, 1 (Kluwer International, Dordrecht, 2000).

13 Alemania, Código Procesal Civil, Zivilprozessordnung, ZPO, 30 de enero de 1877. 
conscientious conviction - ex aquo et bono-determine. They will therefore as a rule consider the arbitrators to be friendly mediators - amiables compositeurs, as the Belgian draft says - and it is obvious that they do so consider them whenever they appoint as arbitrators persons who are not learned in the law. As a rule therefore the goal of arbitration is attained only when the arbitrators are not bound to follow the ordinary rules of law when giving their awards ${ }^{14}$.

Esta particularidad de fundamentar las decisiones ex aquo et bono, de acuerdo con lo correcto y lo bueno, fue de gran recibo en Francia, lugar en que el mecanismo adoptó igualmente la calificación de amiable compositeur ${ }^{15}$. En este caso, el tercero es una persona merecedora de la confianza de las partes (amiable), que lo invisten de las facultades para resolver la controversia por fuera del sistema judicial ${ }^{16}$.

Por lo anterior, en el Derecho francés el concepto de amigable componedor debe entenderse como sinónimo de arbitraje en equidad, arbitraje en conciencia, ex aquo et bono u otras expresiones similares. La misma situación se presenta en el derecho español, como lo prevé la Ley de Arbitraje (Ley 60/2003) ${ }^{17}$ en su Exposición de Motivos (punto VII), entre otros casos. Valga anotar que esta modalidad de arbitraje ha adquirido gran auge en la actualidad por cuenta de los altos niveles de incorporación de la Ley Modelo CNUDMI, la cual contiene una disposición en la que se referencia expresamente la posibilidad de dictar laudos arbitrales basados en estos principios enunciados ${ }^{18}$.

14 Gary B. Born, International Arbitration: Cases and Materials, 1-96 (Aspen Casebook Series, Wolters Kluwer Law International, New York, 2015).

15 Francia, Código de Procedimiento Civil, Code de Procédure Civile, CPC, 14 de abril de 1806. Disponible en: https://archive.org/details/codedeprocdurec00frangoog

16 GARY B. Born, International Arbitration: Cases and Materials, 8 (Aspen Casebook Series, Wolters Kluwer Law International, New York, 2015).

17 España, Ley de Arbitraje, Ley 60/2003, 23 de diciembre, 309 Boletín Oficial del Estado, $B O E, 26$ de diciembre de 2003. Disponible en: https://www.boe.es/buscar/act.php?id=BOEA-2003-23646

18 "Artículo 28. Normas aplicables al fondo del litigio. 1) El tribunal arbitral decidirá el litigio de conformidad con las normas de derecho elegidas por las partes como aplicables al fondo del litigio. (... 3) El tribunal arbitral decidirá ex aequo et bono o como amigable componedor solo si las partes le han autorizado expresamente a hacerlo así". Comisión de las Naciones Unidas para el Derecho Mercantil Internacional, CNUDMI, Ley Modelo sobre Arbitraje Comercial, 1985, con las enmiendas aprobadas en 2006. Disponible en: https:/www.uncitral. org/pdf/spanish/texts/arbitration/ml-arb/07-87001_Ebook.pdf 


\section{El caso colombiano}

\section{En sus orígenes, la amigable composición no fue regulada como el} mecanismo autónomo que actualmente opera. El Código Judicial, consignado en la Ley 105 de 1931, y la Ley 2 de 1938 se refirieron a los árbitros — en los procesos de división de grandes comunidades $-{ }^{19} \mathrm{y}$ a los arbitradores con la posibilidad de emitir fallos en conciencia ${ }^{20}$

${ }^{21}$ o como amigables componedores en los términos del derecho español, que recogió la definición del derecho romano.

Posteriormente, la amigable composición fue consagrada como mecanismo independiente del arbitraje tanto en el Código de Comercio como en el Código de Procedimiento Civil ${ }^{22}$. De las normas mencionadas, es posible colegir que la normativa de la época trataba la amigable composición como una forma de arbitraje ya que esas disposiciones estaban incorporadas entre las normas que regulaban esa materia. Adicionalmente, los referidos artículos no caracterizaban o definían la amigable composición sino que se li-

19 "Artículo 1167. Son atribuciones de los árbitros: (...) 3. Conciliar, y si esto no fuere posible, decidir las opuestas pretensiones de los comuneros, y emplear los medios que, a su juicio, puedan dar por resultado una transacción o composición amigable, caso de que entre estos y los colindantes se susciten cuestiones sobre límites". Colombia, Ley 105 de 1931, sobre organización judicial y procedimiento civil, 21.823 Diario Oficial, 24 de octubre de 1931. Disponible en: http://www.icbf.gov.co/cargues/avance/docs/ley_0105_1931.htm

20 "Artículo 1216. Los interesados deben otorgar una escritura pública o un documento privado, firmado ante dos testigos, extendido en papel sellado, y en que conste: (...) 3. La clase de sentencia que deben dictar los arbitradores, si en derecho, o en conciencia, y si la decisión debe ser simplemente absolutoria o condenatoria, o si puede transigir las pretensiones opuestas. Si falta alguna de estas tres circunstancias, es nulo el compromiso". Colombia, Ley $105 \mathrm{de}$ 1931, sobre organización judicial y procedimiento civil, 21.823 Diario Oficial, 24 de octubre de 1931. Disponible en: http://www.icbf.gov.co/cargues/avance/docs/ley_0105_1931.htm

21 "Artículo 6. Si en la cláusula compromisoria o en acuerdo posterior comunicado a los arbitradores antes de la primera audiencia no se les facultare para fallar en conciencia o para transigir las opuestas pretensiones, la sentencia habrá de ser en derecho". Colombia, Ley $2 \mathrm{de}$ 1938, por la cual se da validez a la cláusula compromisoria, 23.727 Diario Oficial, 12 de marzo de 1938. Disponible en: https://www.cancilleria.gov.co/sites/default/files/Normograma/docs/ ley_0002_1938.htm

22 "Artículo 2025. Sometimiento de diferencias a amigables componedores. En los casos previstos en el inciso primero del artículo (2011 / 663), podrán los interesados someter sus diferencias a amigables componedores; la declaración de estos tiene valor contractual entre aquellos, pero no producirá efectos del laudo arbitral". Colombia, Decreto 410 de 1971, por el cual se expide el Código de Comercio, 33.339 Diario Oficial, 16 de junio de 1971, artículo 2025. Disponible en: http://www.alcaldiabogota.gov.co/sisjur/normas/Norma1.jsp?i=41102. "Artículo 677. Amigables componedores. En los casos previstos en el inciso primero del artículo 663, podrán los interesados someter sus diferencias a amigables componedores; la declaración de estos tiene valor contractual entre aquellos, pero no producirá efectos del laudo arbitral". Colombia, Decreto 1400 de 1970, por el cual se expide el Código de Procedimiento Civil, 33.150 Diario Oficial, 21 de septiembre de 1970. Disponible en: http://www.alcaldiabogota.gov.co/sisjur/ normas/Norma1.jsp?i=6923 
mitaron a demarcar las diferencias entre lo uno y lo otro, a partir de los efectos del laudo y la "declaración con valor contractual" emanada de la amigable composición.

El Decreto 2279 de 1989 en su capítulo II, sección I —De la amigable composición y de la conciliación - dispuso: "las controversias susceptibles de transacción, que surjan entre personas capaces de transigir, podrán ser sometidas a conciliación o amigable composición" 23 . La referida normatividad definió este mecanismo en los siguientes términos: "Por la amigable composición se otorga a los componedores la facultad de precisar, con fuerza vinculante para las partes, el estado y la forma de cumplimiento de una relación jurídica sustancial susceptible de transacción" 24 . Esta fórmula de consagración desligó la figura de la amigable composición de la institución arbitral, la aproximó a la conciliación mediante su incorporación en un capítulo común y le otorgó autonomía como otro mecanismo de solución de controversias.

Seguidamente, la Ley 23 de $1991^{25}$, que derogó los artículos pertinentes del Decreto 2279 de 1989 arriba referido, hizo más patente esa autonomía y ratificó su independencia al disponer en capítulos separados la conciliación (capítulos III, IV, V, VI y VII), el arbitraje (capítulo VIII), y mantener la amigable composición en el capítulo II, sección II del Decreto 2279 de 1989. Una fórmula similar, aunque más explícita, acogió la Ley 446 de $1998^{26}$ que derogó todas las normas sobre el particular vigentes a la fecha y reconoció en la figura un mecanismo del todo separado de los otros sistemas alternativos.

La vigencia de la Ley 446 de 1998 impulsó la utilización de la figura de la amigable composición en Colombia, dadas sus caracte-

23 Colombia, Decreto 2279 de 1989, por el cual se implementan sistemas de solución de conflictos entre particulares y se dictan otras disposiciones, 39.012 Diario Oficial, 7 de octubre de 1989. Disponible en: http://www.icbf.gov.co/cargues/avance/docs/decreto_2279_1989.htm

24 Colombia, Decreto 2279 de 1989, por el cual se implementan sistemas de solución de conflictos entre particulares y se dictan otras disposiciones, 39.012 Diario Oficial, 7 de octubre de 1989. Disponible en: http://www.icbf.gov.co/cargues/avance/docs/decreto_2279_1989.htm

25 Colombia, Ley 23 de 1991, por medio de la cual se crean mecanismos para descongestionar los despachos judiciales, y se dictan otras disposiciones, 39.752 Diario Oficial, 21 de marzo de 1991. Disponible en: https://www.minjusticia.gov.co/portals/0/MJD/docs/ley_0023_1991.htm

26 Colombia, Ley 446 de 1998, por la cual se adoptan como legislación permanente algunas normas del Decreto 2651 de 1991, se modifican algunas del Código de Procedimiento Civil, se derogan otras de la Ley 23 de 1991 y del Decreto 2279 de 1989, se modifican y expiden normas del Código Contencioso Administrativo y se dictan otras disposiciones sobre descongestión, eficiencia y acceso a la justicia, 43.335 Diario Oficial, 8 de julio de 1998. Disponible en: http:// www.secretariasenado.gov.co/senado/basedoc/ley_0446_1998.html 
rísticas de informalidad y la entrada en operación de disposiciones que invitaron a su incorporación en regímenes contractuales y en el ámbito empresarial ${ }^{27}$. Conviene alertar que estas disposiciones no solo ratificaron la vida propia de esta figura sino que además le atribuyeron las características de un contrato complejo, en el que el amigable componedor se constituyó en un verdadero mandatario de las partes cuyas funciones debían contribuir y favorecer el desarrollo de una relación contractual, antes que definir cuestiones relacionadas con su incumplimiento y las responsabilidades derivadas de ello. En materia procedimental, el legislador entendió que un mecanismo eminentemente contractual, en el que sus operadores - a diferencia de la conciliación y el arbitraje - estaban desprovistos de función jurisdiccional, se constituía en una de sus principales ventajas y fortalezas a la hora de optar por un mecanismo ágil, eficiente y apartado del rigor de las instituciones procesales que se aplican en el ámbito judicial.

Finalmente, en lo que respecta a la normatividad vigente, la Ley 1563 de $2012^{28}$ incorporó a la figura una serie de modificaciones derivadas de las experiencias surgidas por cerca de quince años de operación del mecanismo sin ninguna clase de ajuste legislativo o reglamentario.

En un principio, el texto presentado inicialmente por el gobierno nacional ${ }^{29}$ pretendió superar la fórmula dispuesta por la normativa anterior en el sentido de que la función del amigable componedor

27 Con posterioridad a la Constitución de 1991, la amigable composición fue referida en varias normatividades como mecanismo para resolver controversias en materias como contratación administrativa, servicios públicos domiciliarios, acuerdos preconcursales y reestructuración empresarial.

28 Colombia, Ley 1563 de 2012, por medio de la cual se expide el Estatuto de Arbitraje Nacional e Internacional y se dictan otras disposiciones, 48.489 Diario Oficial, 12 de julio de 2012. Disponible en: http://www.secretariasenado.gov.co/senado/basedoc/ley_1563_2012.html

29 "Artículo 58. Definición. La amigable composición es un mecanismo alternativo de solución de conflictos, por medio del cual, dos o más particulares, un particular y una o más entidades públicas, o varias entidades públicas, o un particular con ocasión de su ejercicio de funciones públicas, delegan en un tercero, denominado amigable componedor, la facultad de definir, con fuerza vinculante para las partes, una controversia de libre disposición. Artículo 59. Efectos. La decisión del amigable componedor producirá los efectos legales propios de la transacción. Artículo 60. Designación. Las partes podrán nombrar al amigable componedor directamente o delegar en un tercero su designación. El tercero delegado por las partes para nombrar al amigable componedor puede ser una persona natural o jurídica". Informe de ponencia para primer debate al Proyecto de Ley 18 de 2011 Senado, por medio de la cual se expide el Estatuto de Arbitraje Nacional e Internacional y se dictan otras disposiciones, 817 Gaceta del Congreso, 2 de noviembre de 2011. Disponible en: http://www.imprenta.gov.co/gacetap/gaceta.nivel_3 
no debía limitarse a definir "el estado, las partes y la forma de cumplimiento de un negocio jurídico particular" sino a "definir, con fuerza vinculante para las partes, una controversia de libre disposición”. Esta propuesta tuvo como finalidad ampliar el ámbito de competencias de una figura cada vez más utilizada para la resolución definitiva de un conflicto que como un mecanismo para precisar aspectos de una relación contractual. En tal sentido, el texto finalmente aprobado por el Congreso de la República incluyó esta particular alternativa mediante una fórmula más detallada, así: “(...) en su decisión, podrá precisar el alcance o forma de cumplimiento de las obligaciones derivadas de un negocio jurídico, determinar la existencia o no de un incumplimiento contractual y decidir sobre conflictos de responsabilidad suscitados entre las partes, entre otras determinaciones". También se hizo explícito en el articulado final que el amigable componedor actúa como mandatario de las partes, lo que ratifica aún más la condición de mecanismo de carácter contractual, no jurisdiccional.

En cuanto al contenido y la forma de la decisión, se consagró que la misma puede fundamentarse en la equidad, salvo convención en contrario, sin perjuicio de que el amigable componedor haga uso de reglas de derecho, de considerarlo conveniente. Así mismo, se estipuló que esta produce los efectos legales propios de la transacción.

En relación con el aspecto procedimental, resulta evidente que la connotación contractual del mecanismo no ha escapado a la idea de judicializarlo. En efecto, durante el trámite del Proyecto de Ley 176 de 2011 (Cámara) y 018 de 2011 (Senado), tercer debate, el Ministerio Público, al que se le atribuyeron funciones para participar de los trámites de amigable composición en los que es parte una entidad pública o quien desempeñe funciones administrativas, tramitó la inclusión de un verdadero procedimiento para regular la operación de esta figura ${ }^{30}$.

30 Informe de ponencia para primer debate al Proyecto de Ley 176 de 2011 Cámara, 18 de 2011, Senado, por medio de la cual se expide el Estatuto de Arbitraje Nacional e Internacional y se dictan otras disposiciones, 108 Gaceta del Congreso, 27 de marzo de 2012. Disponible en: http://www.imprenta.gov.co/gacetap/gaceta.nivel_3. En el informe de ponencia para primer debate al proyecto de Ley 176 de 2011 Cámara, 18 de 2011 Senado, se lee: "En el artículo 59 sobre amigable composición se incluye la expresión 'o quien desempeñe funciones administrativas'. Adicionalmente, se establece todo un procedimiento para la amigable composición, propuesto por la Procuraduría General de la Nación, con el fin de dar claridad". En el texto incorporado por los ponentes, se dispuso: "Artículo 59. Definición. (...) Aceptado el nombra- 
Esta particular visión que involucraba un claro desmedro a la aplicación del principio de la autonomía de la voluntad en este mecanismo contractual, fue desestimado por el Congreso de la República para el último debate, en los siguientes términos: "Artículo 59. Definición. Contiene dos (2) modificaciones este artículo de amigable composición. (...) La segunda, se elimina todo el procedimiento establecido, habida cuenta de que en las discusiones primaron más las razones que indican que se trata de una institución de índole contractual, a la que es extraño el hecho de que se le fijen normas que reglan ese mecanismo por etapas, al mejor estilo de un proceso" 31 .

Visto lo anterior, el legislador se desprendió de las fórmulas procedimentales para regular el curso de los trámites de amigable composición, dado que entendió que su naturaleza contractual $-\mathrm{y}$ no jurisdiccional - era componente suficiente para admitir una mayor prevalencia de la autonomía de la voluntad. Por tal razón, se determinó que el procedimiento puede ser fijado por las partes directamente, o por referencia a un reglamento de amigable composición de un centro de arbitraje, tomando como presupuesto el

miento, el amigable componedor convocará a una audiencia de apertura, en la que delimitará su autoridad, fijará su alcance y la naturaleza de la disputa, duración del trámite, instará a las partes para que presenten los elementos de juicio que pretendan hacer valer y fijará los honorarios a su favor, que deberán ser consignados por partes iguales en el término que se señale.

Si alguna de las partes no consigna oportunamente, lo hará por ella la otra, en un término que no exceda de cinco (5) días siguientes al vencimiento del término inicial. No obstante, tratándose de entidades públicas o de quien desempeñe funciones administrativas, si esta no consignare se entenderá extinguido el pacto de amigable composición.

Consignados los honorarios, el amigable componedor señalará las oportunidades en las que adelantará entrevistas con partes y terceros, examinará documentos y adelantará gestiones para formar su propio juicio. Concluida esta etapa, el amigable componedor invitará a las partes a exponer las razones de esgriman $[s i c]$ a favor de sus respectivas causas, para lo cual señalará fecha y hora, indicando el término con que cuentan para intervenir. Cuando sea parte una entidad pública o quien desempeñe funciones administrativas, el Ministerio Público y la Agencia Nacional de Defensa Jurídica del Estado podrán emitir concepto en el mismo término y oportunidad, si lo consideran conveniente.

El amigable componedor definirá la fórmula contractual a la cual deberán someterse las partes y la explicará en sesión que fijará para tal efecto. La fórmula contractual definida por el amigable componedor no es susceptible de ningún recurso.

La decisión del amigable componedor en la que decline la facultad de definir la controversia, dejará sin efectos el pacto de amigable composición y cualquiera de las partes podrá iniciar las acciones que correspondan ante la respectiva jurisdicción". Informe de ponencia segundo debate proyecto de ley 176 de 2011 Cámara, 18 de 2011 Senado, ¿Ley de Arbitraje Nacional e Internacional?, 321 Gaceta del Congreso, 6 de junio de 2012. Disponible en: http://www. imprenta.gov.co/gacetap/gaceta.nivel_3

31 Informe de ponencia segundo debate proyecto de ley 176 de 2011 Cámara, 18 de 2011 Senado, ¿Ley de Arbitraje Nacional e Internacional?, 321 Gaceta del Congreso, 6 de junio de 2012. Disponible en: http://www.imprenta.gov.co/gacetap/gaceta.nivel_3 
respeto a los derechos de las partes a la igualdad y a la contradicción de argumentos y pruebas.

\section{Similitudes en el derecho comparado}

En la actualidad, subsiste en Italia una figura paralela al arbitraje tradicional y con profundas similitudes a la amigable composición reconocida en nuestro ordenamiento jurídico, denominada "arbitraje irritual" 32 . Esta figura se constituye en una expresión de los usos y prácticas mercantiles contemporáneas y deja entrever la existencia de dos categorías de arbitraje, no obstante el hecho de que la ley las define dentro de una única categoría jurídica. El arbitraje dispuesto en la codificación se denomina arbitraje ritual mientras que las otras fórmulas recogidas de la práctica contienen procedimientos asimilables a este pero con unas particularidades que las alejan de la versión tradicional. Así, el árbitro "irritual" no ostenta funciones jurisdiccionales sino que se constituye en un tercero que despliega una actividad eminentemente contractual, en la condición de mandatario de las partes habilitado para resolver una controversia.

El arbitraje irritual es considerado por la doctrina como una de las formas más elementales o primitivas de arbitraje, debido a su total desprendimiento de las formas procesales y de los formalismos. Los límites fijados a esta particular forma de transacción entre las partes están marcados por el derecho de defensa y el principio de contradicción entre las partes. El rigor formal propio del arbitraje codificado — que de todas maneras presenta grandes diferencias respecto del proceso judicial clásico - resulta en todo inapropiado para la resolución de pequeñas causas o de controversias que requieren respuestas expeditas y con mínimas inversiones en términos económicos. Por ello, esta modalidad de arbitraje se mantiene vigente y es una figura a la que se recurre regularmente para resolver algunos conflictos de carácter mercantil.

En este orden de ideas, es posible enmarcar el arbitraje irritual en un ámbito eminentemente negocial. La decisión que se toma por parte de los árbitros se denomina igualmente laudo arbitral y

32 Italia, Regio decreto-legge 1443, 28 ottobre 1940, Codice di Procedura Civile. Disponible en: http://www.normattiva.it/uri-res/N2Ls?urn:nir:stato:decreto.regio:1940-10-28;1443!vig= 
su carácter vinculante está dado por el artículo 1372 del Código Civil $^{33}$. No obstante, el no acatamiento de esta decisión acarrea una especie de incumplimiento contractual, susceptible de ser sometido a consideración de los jueces de instancia. Esta particularidad hace al arbitraje irritual una figura sustancialmente distinta del arbitraje ritual cuyos efectos, después de la más reciente reforma efectuada en el país, corresponden a los de una sentencia judicial anulable en los términos del Código de Rito o Código Civil.

\section{B. Discusiones alrededor de la naturaleza autocompositiva/heterocompositiva de la amigable composición}

Para realizar una aproximación al tratamiento constitucional del principio de la autonomía de la voluntad en la materia, resulta necesario develar, en primera instancia, la naturaleza del mecanismo objeto de estudio y su calificación como un sistema de autocomposición o heterocomposición, dadas sus características sui generis en el derecho colombiano.

\section{El mandato y la representación como elementos que dan origen a la autocomposición}

En efecto, los mecanismos puramente autocompositivos suelen involucrar exclusivamente a las partes a la hora de adoptar la decisión; mientras que en los heterocompositivos, la definición del conflicto suele emanar de un tercero que opera con total autonomía. En el caso de la amigable composición, hemos visto que, a diferencia de lo que ocurre en el derecho comparado, no se trata de un arbitraje en el que el árbitro decide ex aquo et bono, sino de una alternativa en la que el tercero obra como mandatario de las partes, con total autonomía para decidir la forma de cumplimiento de un negocio jurídico particular o para decidir cuestiones de incumplimiento y

33 "Articolo 1372. Efficacia del contratto. Il contratto ha forza di legge tra le parti. Non può essere sciolto che per mutuo consenso o per cause ammesse dalla legge $(1671,2227)$. Il contratto non produce effetto rispetto ai terzi che nei casi previsti dalla legge $(1239,1300$ e seguente, 1411, 1678, 1737)". Italia, Regio decreto-legge 262, 16 marzo 1942, Approvazione del testo del Codice Civile. Disponible en: http://www.jus.unitn.it/cardozo/obiter_dictum/codciv/Codciv. htm 
responsabilidad según la fórmula vigente adoptada en la Ley 1563 de 2012.

En primer lugar, es pertinente anotar que el punto relativo al mandato fue objeto de debate bajo los regímenes anteriores. Autores nacionales como JoRGE HERNÁN GIL-ECHEVERRY consideraban que el vínculo entre el amigable componedor y las partes no correspondía a esa figura en el ordenamiento mercantil, ya que en los términos del artículo 1262 del Código de Comercio ${ }^{34}$, el mandatario se obliga a ejecutar uno o más actos comercio por cuenta del mandante, lo que no acontece con la amigable composición. Para reafirmar su posición, advierte el autor que el amigable componedor tiene la obligación de actuar con total autonomía e independencia, comportamiento incompatible con lo dispuesto en el artículo $1266^{35} \mathrm{de}$ la normatividad mercantil que obliga al mandatario a sujetarse a las instrucciones del mandante y a proteger sus intereses ${ }^{36}$.

La posición contraria ha sido esgrimida por diversos autores como José Alejandro Bonivento, Roberto Valdés-Sánchez, Enrique Gaviria-Gutiérrez y Alejandro Venegas-Franco, entre otros. De la misma manera, la Corte Constitucional se inclinó por esta teoría, en los siguientes términos:

Dicho vínculo que se establece entre el amigable componedor y las partes tiene su origen en un contrato de mandato, cuyas facultades se limitan conforme a lo establecido en el contrato de composición. Así las cosas, la amplitud de las

34 "Artículo 1262. Definición de mandato comercial. El mandato comercial es un contrato por el cual una parte se obliga a celebrar o ejecutar uno o más actos de comercio por cuenta de otra. El mandato puede conllevar o no la representación del mandante. Conferida la representación, se aplicarán además las normas del Capítulo II del Título I de este Libro". Colombia, Decreto 410 de 1971, por el cual se expide el Código de Comercio, 33.339 Diario Oficial, 16 de junio de 1971. Disponible en: http://www.alcaldiabogota.gov.co/sisjur/normas/Norma1.jsp?i=41102

35 "Artículo 1266. Límites del mandato y actuaciones. El mandatario no podrá exceder los límites de su encargo. Los actos cumplidos más allá de dichos límites solo obligarán al mandatario, salvo que el mandante los ratifique. El mandatario podrá separarse de las instrucciones, cuando circunstancias desconocidas que no puedan serle comunicadas al mandante, permitan suponer razonablemente que este habría dado la aprobación". Colombia, Decreto 410 de 1971, por el cual se expide el Código de Comercio, 33.339 Diario Oficial, 16 de junio de 1971. Disponible en: http://www.alcaldiabogota.gov.co/sisjur/normas/Norma1.jsp?i=41102

36 Jorge Hernán Gil-Echeverry, La conciliación extrajudicial y la amigable composición, 408 (Editorial Temis, Bogotá, 2011). 
actuaciones que adelante el amigable componedor dependerá de las restricciones o no que se le fijen por parte [de] sus mandatarios ${ }^{37}$.

Desde nuestro punto de vista, esta postura se reafirmó sin lugar a equívocos en la normatividad actual, pues en ella se expresó de manera explícita la condición de "mandatario" del amigable componedor. De esta premisa se desprende que tanto en el régimen anterior como en el vigente ha prevalecido la posición sobre el carácter autocompositivo de la amigable composición.

\section{Aproximación funcional de la amigable composición a otros mecanismos heterocompositivos como el arbitraje}

No obstante lo anterior, para autores como MARIO RICARDO OSORIO-HERnÁndez, el hecho de que el amigable componedor sea un representante de las partes no es elemento determinante para atribuirle el carácter de mecanismo autocompositivo. En efecto, la irrevocabilidad de la representación; la facultad de precisar (o definir) con "fuerza vinculante" el estado, las partes y la forma de cumplimiento de un negocio jurídico particular (o una controversia contractual de libre disposición) no son características propias de un mecanismo de autocomposición ${ }^{38}$.

En este sentido, el hecho de que la decisión sea impuesta y que no se persiga un acercamiento amigable para que sean las mismas partes las que solucionen su controversia constituye un claro ejemplo de heterocomposición. De la misma manera, OSORIO-HERnÁNDEZ se aparta del argumento de la Corte Constitucional según el cual el carácter autocompositivo se distingue por la posibilidad de definir el procedimiento directamente por las partes mientras que en los casos de heterocomposición la tramitación está sujeta a una regulación legal específica, por cuanto ello desconoce el carácter eminentemente contractual del arbitraje internaciona ${ }^{39}$.

37 Colombia, Corte Constitucional, Sentencia T-017-05, 20 de enero de 2005, magistrado ponente Rodrigo Escobar-Gil, Fundamentos jurídicos de la Corte, 11. Disponible en: http://www. corteconstitucional.gov.co/relatoria/2005/t-017-05.htm

38 Mario Ricardo Osorio-Hernández, Amigable composición y arbitraje en equidad: pasado presente y futuro de dos engendros colombianos, en Ensayos arbitrales, 13-26 (Cámara de Comercio de Bogotá, Kimpres, Bogotá, 2010).

39 Mario Ricardo Osorio-Hernández, Amigable composición y arbitraje en equidad: pasado 
Ahora bien, independiente de las consideraciones teóricas que se tomen en cuenta para calificar esta figura, es necesario considerar que en la práctica es utilizada como mecanismo definitorio mediante el cual se sustrae la controversia del conocimiento de los jueces para atribuir la tarea a particulares, aunque estos no estén investidos de función jurisdiccional ${ }^{40}$.

Desde la perspectiva del procedimiento civil, el pacto de amigable composición ha sido asimilado al pacto arbitral en lo relativo a los efectos que produce frente a la competencia de los jueces. Aunque en las normativas procesales la cláusula de amigable composición no se encuentra contemplada como excepción previa, algunos autores afirman que en virtud del principio de economía procesal y de la prelación del derecho sustantivo sobre el procesal, esta puede proponerse como una excepción de tal categoría en cualquier proceso judicial. En efecto, resultaría contrario a estos principios que el juez desconociera su existencia desde el inicio del proceso para reconocer finalmente en la sentencia una excepción sustantiva de incumplimiento contractual por no haber acudido el demandante a resolver su controversia por la vía de la amigable composición ${ }^{41}$.

\section{LA AUTONOMÍA DE LA VOLUNTAD EN EL ÁMBITO DE LOS MECANISMOS ALTERNATIVOS DE SOLUCIÓN DE CONFLICTOS EN GENERAL Y LA AMIGABLE COMPOSICIÓN EN PARTICULAR}

La Corte Constitucional ha reiterado en múltiples pronunciamientos que el propósito fundamental de la administración de justicia es hacer realidad los principios y valores que inspiran al Estado

presente y futuro de dos engendros colombianos, en Ensayos arbitrales, 13-26 (Cámara de Comercio de Bogotá, Kimpres, Bogotá, 2010).

40 En lo que respecta a la amigable composición, llama la atención lo señalado por la Corte Constitucional, al manifestar: "Lo mismo ocurre con la amigable composición. Como el arbitramento, sustrae el conflicto legalmente puesto a su conocimiento, de la jurisdicción estatal; y su decisión, al igual que el laudo arbitral, produce los efectos legales relativos a la transacción (Ley 446 de 1998, artículo 131), esto es, el efecto de cosa juzgada (Código Civil, artículo 2483) que le brinda a la amigable composición fuerza definitoria. Por eso, la misma, en las condiciones establecidas en el artículo demandado, tampoco puede entenderse como una limitación del derecho de acceso a la justicia". Colombia, Corte Constitucional, Sentencia C-014-10, 20 de enero de 2010, magistrado ponente Mauricio González-Cuervo, Consideraciones de la Corte, 4.1.4. Disponible en: http://www.corteconstitucional.gov.co/relatoria/2010/c-014-10.htm

41 Jorge Hernán Gil-Echeverry, La conciliación extrajudicial y la amigable composición, 22 (Editorial Temis, Bogotá, 2011). 
Social de Derecho contenidos en el Preámbulo y los artículos 1 y 2 de la Carta Política, entre los cuales se encuentran la paz, la tranquilidad, el orden justo y la armonía de las relaciones sociales. Para el alto tribunal, es claro que esas metas se hacen realidad no solo mediante el pronunciamiento formal y definitivo de un juez de la República, sino que también es posible lograrlo acudiendo a la amigable composición o a la intervención de un tercero que no forme parte de la rama judicial. Con la implementación de estos mecanismos alternativos de resolución de conflictos, se evita a las partes poner en movimiento el aparato judicial del país y se busca que por medio de estas instituciones los interesados puedan llegar en forma pacífica y amistosa a solucionar determinadas diferencias, incluso aquellas que plantean la presencia de complejidades de orden jurídico ${ }^{42}$.

\section{A. Autonomía de la voluntad, libertad y mecanismos alternativos de solución de conflictos}

Para materializar el ideal de justicia, el legislador cuenta con la competencia para fijar las formas de composición de los conflictos, tanto en el plano judicial como en el extrajudicial, todo de conformidad con los parámetros establecidos en la Carta Política. En el primer caso, define las características del proceso, que en palabras de Francesco Carnelutti es "el conjunto de actos coordinados y sucesivos realizados por los órganos investidos de jurisdicción y los demás sujetos que actúan, a fin de obtener la aplicación de la ley sustancial o material a un caso concreto" ${ }^{\text {"43 }}$. En el segundo, establece las particularidades y las fórmulas mínimas a partir de las cuales los ciudadanos entre sí, o los ciudadanos y el Estado someten sus controversias a mecanismos que no implican el ejercicio de la administración de justicia, como en el caso de la amigable composición.

No obstante, para promover los mecanismos alternativos de solución de conflictos, el legislador no requiere entrar a tipificar y a regular las singularidades de todas y cada una de las figuras que

42 Colombia, Corte Constitucional, Sentencia C-037-96, 5 de febrero de 1996, magistrado ponente Vladimiro Naranjo-Mesa. Disponible en: http://www.corteconstitucional.gov.co/ relatoria/1996/C-037-96.htm

43 Francesco Carnelutti, Derecho procesal civil y penal (Ediciones Jurídicas, Europa América, Buenos Aires, 1971). 
tienen como finalidad resolver un conflicto de manera definitiva o permitir un acercamiento entre las partes para llegar a ello. En efecto, mediante la puesta en práctica de los principios de voluntariedad y la autonomía de la voluntad, los interesados en zanjar sus disputas pueden configurar un sinnúmero de alternativas mediante las cuales, de manera ágil y con un mínimo de recursos invertidos, alcancen los presupuestos de convivencia pacífica sin necesidad de recurrir a las instancias judiciales.

Los métodos alternativos de solución de controversias se caracterizan entonces por su carácter informal y por la menor incidencia que tienen las normatividades propias de los procesos que se adelantan en sede judicial. En este punto, la autonomía de la voluntad juega un papel sustancial ya que lo frecuente y regularmente aceptado es que sean las mismas partes o los terceros habilitados por ellas quienes dispongan las etapas y condiciones en las que se acceda a una pronta decisión o recomendación que permita la celebración de un acuerdo dispuesto por los mismos interesados.

En España, el Tribunal Constitucional no ha dudado en señalar reiteradamente que la autonomía de la voluntad de los sujetos privados en la que se fundan los métodos alternativos, está constitucionalmente vinculada con la libertad como valor superior del ordenamiento $^{44}$. Este principio de autonomía de la voluntad es, sin duda alguna, el principio en torno al que giran regularmente los procedimientos de los mecanismos consagrados en los diversos ordenamientos jurídicos.

Así como lo menciona José Carlos Fernández-Rozas, refiriéndose particularmente al arbitraje, es posible afirmar también que los métodos alternativos llegan "exclusivamente hasta donde alcanza la libertad, que es su fundamento y motor y ese ámbito de libertad también tiene un respaldo constitucional, concretamente en el artículo 33 de la Constitución Española, que reconoce el derecho a la propiedad privada, fundamentado en los postulados de la libertad económica y de la autonomía de la voluntad, y en el

44 España, Tribunal Constitucional, Sentencia 176/1996, 11 de noviembre, 303 Boletín Oficial del Estado, BOE, 17 de diciembre de 1996. Disponible en: http://hj.tribunalconstitucional.es/ es/Resolucion/Show/3228 
artículo 38 que estatuye el principio de libertad de empresa en el marco de la economía de mercado" ${ }^{45}$.

Los mecanismos de esta clase son atractivos para los hombres de negocios y para la comunidad en general, entre otras razones, porque están desprovistos de excesivos formalismos y porque su libertad configurativa permite cumplir sus objetivos de manera expedita, con plena eficacia y seguridad. Estas consideraciones resultan plenamente aplicables para los llamados mecanismos autocompositivos pero adquieren especial interés cuando los beneficios enunciados se revierten en mecanismos heterocompositivos o de "adjudicación", como podría entenderse en el caso de la amigable composición.

\section{B. Autonomía de la voluntad y la amigable composición}

Como se ha planteado a lo largo de este texto, la amigable composición se ha constituido como una figura autónoma en el derecho colombiano, con vida propia respecto del arbitraje, ya que poco o nada comparte en su definición legal con esta otra figura, de carácter eminentemente jurisdiccional. Estas profundas diferencias - que en nada replican los modelos del derecho comparado - han determinado en gran medida las formas propias del trámite, el cual, como regla general en los diversos períodos de su regulación, nada tienen qué ver con las complejas formas que se prevén regularmente para estructurar los procesos judiciales, incluido el arbitraje.

Desde esta perspectiva eminentemente regulatoria, podemos entender que la ausencia de normas contempladas para definir el

45 José Carlos Fernández-Rozas, Arbitraje y jurisdicción: una interacción necesaria para la realización de la justicia, 13 Derecho Privado y Constitución, Centro de Estudios Politicos y Constitucionales, CEPC, Madrid, 19, 55-91 (2005). Disponible en: http://eprints.ucm.es/6573/1/ ARBITRAJE_Y_JURISDICCION.pdf. "Artículo 33. 1. Se reconoce el derecho a la propiedad privada y a la herencia. 2. La función social de estos derechos delimitará su contenido, de acuerdo con las leyes. 3. Nadie podrá ser privado de sus bienes y derechos sino por causa justificada de utilidad pública o interés social, mediante la correspondiente indemnización y de conformidad con lo dispuesto por las leyes. Artículo 38. Se reconoce la libertad de empresa en el marco de la economía de mercado. Los poderes públicos garantizan y protegen su ejercicio y la defensa de la productividad, de acuerdo con las exigencias de la economía general y, en su caso, de la planificación”. España, Constitución española, 27 de diciembre, 311 Boletín Oficial del Estado, BOE, 29 de diciembre de 1998. Disponible en: https://www.boe. es/diario_boe/txt.php?id=BOE-A-1978-31229 
entorno y las formas como las partes y el amigable componedor deben actuar, constituye un ambiente propicio para que los unos y los otros formulen modelos y esquemas adecuados para cada tipo de conflicto y sus necesidades particulares. Esta conclusión parece evidente si comparamos el escueto articulado de la amigable composición con el nutrido de otras figuras como la conciliación y el arbitraje, que incluso se complementa con las normativas procesales vigentes.

Otro elemento que debe llamar la atención sobre este particular es el hecho de que el amigable componedor juega el papel de un mandatario de las partes. Esta visión es ratificada por la normativa actual pero ya era de recibo para importantes sectores de la doctrina bajo las múltiples disposiciones derogadas que la contemplaron en el pasado. En tal sentido, la visión de la amigable composición como mecanismo autocompositivo apunta a que bien sea porque las partes definen directamente las formas del "procedimiento" aplicable o bien porque quien lo hace es el amigable componedor, en ambos casos estamos ante una manifestación de voluntad de las primeras y por consiguiente los límites que el legislador o los jueces impongan deben entenderse como verdaderas restricciones al libre ejercicio de la autonomía contractual en este campo.

\section{Perspectiva del ordenamiento legal vigente}

A diferencia de las normas derogadas, las disposiciones contenidas en la Ley 1563 de 2012 hicieron mención específica sobre aspectos del procedimiento que deben ser tenidos en cuenta a la hora de adelantar un trámite de amigable composición. Sin embargo, estos preceptos están dispuestos de una manera muy general y otorgan especiales prerrogativas a los acuerdos privados que prevalecen sobre una serie de reglas supletivas, normalmente referencias a reglamentos de centros prestadores del servicio.

En primera medida, las disposiciones referidas aluden a la forma de nombrar los amigables componedores y establecen como regla predominante los acuerdos de voluntades expresados en tal sentido, bien sea que el amigable componedor sea designado de manera directa por las partes o de manera indirecta, por intermedio de un ente nominador escogido por estas. Las normas sobre el particu- 
lar contienen igualmente una "válvula de escape", que asigna la facultad nominativa de los amigables componedores a los centros de arbitraje y amigable composición cuando las partes no pudieren efectuar los nombramientos requeridos para adelantar la labor.

En segundo lugar, la normativa pertinente refiere a los aspectos específicos del procedimiento sin hacer ninguna alusión a etapas o a fórmulas específicas del derecho procesal, que es lo más adecuado por la naturaleza del trámite en cuestión. Estas disposiciones establecen que el procedimiento de la amigable composición podrá ser fijado por las partes directamente, o por referencia a un reglamento de amigable composición de un centro de arbitraje.

Sobre este particular, las partes tienen plenas libertades para configurar la estructura de su trámite y las únicas limitantes contempladas por esta normatividad son "los derechos de las partes a la igualdad y a la contradicción de argumentos y pruebas", una fórmula suficientemente amplia para implementar un mecanismo cuya efectividad radica precisamente en su flexibilidad y versatilidad en el abordaje de controversias no solo de carácter privado sino también de aquellas de gran complejidad en las que participan entidades públicas, como la misma ley lo establece.

Un elemento para considerar en la práctica tiene qué ver con el importante papel que juegan los reglamentos de los centros de arbitraje y amigable composición en relación con el procedimiento. En atención a que la ley dispone solo unos criterios generales y no precisa los detalles sobre la manera en la que se adelantarán materialmente los trámites, resulta evidente que en la actualidad se desarrollan dos grandes modalidades de amigable composición: en primer lugar, los trámites "privados" adelantados bajo las formas contractuales dispuestas por las partes; y en segundo lugar, los de carácter "institucional" que tienen lugar al amparo de los centros y en las condiciones establecidas por su propia reglamentación.

Resulta necesario precisar que la naturaleza de los centros de arbitraje y amigable composición es eminentemente privada, por lo que las partes optan por recurrir a ellos en virtud de los beneficios que como institución representan. La alternativa de adelantar un trámite de amigable composición por la vía "privada" o "institucional" estará seguramente influenciada, entre otras cosas, por la calidad, eficiencia y compatibilidad que el reglamento del centro 
suponga en relación con las necesidades específicas de las partes y su conflicto. De la misma manera, la "competencia" entre los centros por atraer casos debe ir más allá de lo meramente institucional y lo que estos signifiquen en términos de mera infraestructura, al destacar particularmente sus listas de profesionales y, por supuesto, la idoneidad de sus reglamentos.

En otras palabras, la decisión libre y soberana de las partes de optar o no por una u otra institución es una manifestación de la autonomía de la voluntad que puede verse afectada, o por lo menos disminuida, si estos entes privados encuentran, a su vez, limitaciones a la hora de configurar sus estatutos según su propio criterio. Tal como se ha señalado, los presupuestos legales sobre el particular resultan en gran medida favorables para que partes e instituciones arbitrales compitan en un "libre mercado de normas" en las que los últimos beneficiados resulten ser los directamente interesados en la resolución de sus conflictos.

En virtud de lo anteriormente señalado, llama particularmente la atención que en este entorno de libertad contractual, el gobierno, mediante su poder reglamentario, incida de manera directa en la forma en que los privados (centros de arbitraje y amigable composición) optan por definir sus parámetros estatutarios en esta materia ${ }^{46}$.

Como lo hemos mencionado, las características del arbitraje como mecanismo jurisdiccional consagrado constitucionalmente, difieren en gran medida de aquellas que la ley y la jurisprudencia le han atribuido a la amigable composición. No obstante, la mencionada regulación admite un nivel de intervención estatal similar para el caso de las dos figuras por lo que parece que en criterio del legislador, por lo menos en este ámbito, tienen un carácter inescindible.

46 Los fundamentos y los parámetros que admiten esta intervención aparecen en la misma Ley 1563 de 2012, que dispone: "Artículo 51. Reglamentos de los centros de arbitraje. Cada centro de arbitraje expedirá su reglamento, sujeto a la aprobación del Ministerio de Justicia $y$ del Derecho, que deberá contener: 1 . El procedimiento para la conformación de las listas de árbitros, amigables componedores y secretarios, los requisitos que ellos deben reunir, las causas de su exclusión, los trámites de inscripción, y la forma de hacer su designación. (...) 4. Los mecanismos de información al público en general relativa a los procesos arbitrales y las amigables composiciones. (...) 7. Las reglas de los procedimientos arbitrales y de amigable composición, con el fin de que estos garanticen el debido proceso. Artículo 52. Control, inspección y vigilancia. El Ministerio de Justicia y del Derecho ejercerá el control, inspección y vigilancia de los centros de arbitraje" (cursivas añadidas). 
En la práctica, el Ministerio de Justicia y del Derecho ha tomado una serie de medidas en las que predispone la estructura de los reglamentos de los centros de arbitraje y de amigable composición mediante instrumentos de unificación que tienen como destinatarios los entes que están bajo su "control, inspección y vigilancia". En efecto, bajo el criterio de la "necesidad de dotar a los diferentes Centros de Arbitraje, Conciliación y Amigable Composición que se encuentran bajo la vigilancia del Ministerio de Justicia y del Derecho, de una herramienta que realice una aproximación, lo más completa posible, al mínimo con el que deben contar los Reglamentos Internos de los Centros de Arbitraje, Conciliación y Amigable Composición" 47 se promovió el "Modelo Reglamento para Centros de Conciliación, Arbitraje y Amigable Composición"48 que reúne, en un único estatuto, las regulaciones sobre estos tres métodos alternativos de solución de controversias.

Llama la atención que el modelo estatutario propuesto reitera el carácter contractual de la amigable composición en el sentido de que las partes tendrán facultades para configurar los aspectos instrumentales del trámite. No obstante, establece que los amigables componedores de los centros de arbitraje deberán seguir, en todo caso y aun en detrimento de lo estipulado expresamente por los interesados, unas reglas preestablecidas en estas normas modeladoras ${ }^{49}$.

47 Programa Nacional de Conciliación, Modelo de Reglamento Interno para Centros de Conciliación Arbitraje y Amigable Composición. Disponible en: http://conciliacion.gov.co/portal/ documentos

48 Programa Nacional de Conciliación, Modelo de Reglamento Interno para Centros de Conciliación Arbitraje y Amigable Composición. Disponible en: http://conciliacion.gov.co/portal/ documentos

49 "Artículo 61. Procedimiento. La fijación del procedimiento, por medio del cual se guiará la actuación del amigable componedor corresponderá a las partes, quienes podrán incluirlo también en el mandato. Sin embargo para todos los efectos, los amigables componedores del Centro se guiarán por las siguientes reglas generales: 1) La amigable composición comenzará con la celebración de una audiencia, que tendrá como objetivo primordial conocer las diferentes posiciones de las partes sobre el conflicto; en esta audiencia, el amigable componedor deberá mediar entre las partes para identificar conjuntamente una solución al conflicto. 2) Culminada la audiencia anterior con imposibilidad de acuerdo, el amigable componedor señalará la evidencia documental que considere necesaria, y en este sentido, solicitará a las partes que entreguen las que estén en su alcance aportar. 3) El amigable componedor dispondrá de un (1) mes, contado desde la recepción de las pruebas documentales que haya solicitado, para hacer una valoración integral del caso y emitir una decisión de fondo sobre la controversia. 4) La decisión que se tome deberá constar en acta suscrita por el amigable componedor, cuyo contenido deberá como mínimo reflejar el desarrollo del proceso, las consideraciones técnicas o jurídicas que haya tenido en cuenta, una justificación de la decisión tomada, y 
El intento unificador del ente gubernamental resulta a todas luces contrario al espíritu de libertad contractual que la ley dispuso para la amigable composición pues sugiere a los centros - entes de naturaleza privada - unos estándares regulatorios mínimos y la disposición de una serie de etapas que ponen de manifiesto su interpretación sobre lo que significa el respeto a la "igualdad y la contradicción de argumentos y pruebas". Estos principios fueron efectivamente dispuestos en la ley como límites a la autonomía contractual pero jamás fueron contemplados por esta en los términos que esta normativa propone. Adicionalmente, las disposiciones señaladas desconocen la posibilidad de que las partes involucradas en la solución del conflicto definan y estructuren los alcances del procedimiento bajo su propio criterio mediante la supresión de etapas, la disminución de términos o incluso dotando de mayor informalidad la decisión del tercero, pues este reglamento establece que los mínimos señalados serán aplicables "para todos los efectos".

No obstante lo anterior, pese a las funciones que desarrolla el Ministerio de Justicia y del Derecho en relación con los centros de arbitraje y amigable composición, y a su expresión unificadora plasmada en el señalado documento, estos entes administradores de trámites han contado con un nivel de autonomía tal que han podido regular el procedimiento de la amigable composición de forma diversa a la propuesta por el gobierno nacional.

En efecto, reglamentos como el del Centro de Arbitraje y Conciliación de la Cámara de Comercio de Bogotá ${ }^{50}$ —uno de los de mayor impacto nacional en el desarrollo de métodos alternativos de solución de conflictos-dispusieron en sus estatutos sobre amigable composición una serie de fórmulas que constituyen una clara expresión de la autonomía de la voluntad privada combinada con fórmulas que permiten impulsar el trámite bajo el criterio del amigable componedor que, a su vez, debe guiarse por los principios de "igualdad de armas" promulgados en la correspondiente Ley".

la descripción de los compromisos que en virtud de la decisión deben satisfacer las partes" (cursivas añadidas).

50 Cámara de Comercio de Bogotá, Centro de Arbitraje y Conciliación, Reglamentos. Reglamento de amigable composición. Disponible en: http://www.centroarbitrajeconciliacion.com/ Servicios/Arbitraje/Reglamento-y-normatividad, http://www.centroarbitrajeconciliacion.com/ content/download/9245/122796/file/Reglamento\%20amigable\%20composici\%C3\%B3n.pdf

51 En primera instancia, se resalta la disposición contentiva de los estándares que deben regir el trámite, en los siguientes términos: "Artículo 7.1. Ámbito de aplicación. (...) 3. Los vacíos en 
Estas disposiciones suponen fórmulas de gran utilidad para trámites de esta naturaleza pues los amigables componedores no están atados a esquemas reglamentarios estrictos y bajo su criterio, pueden liderar el desarrollo del trámite según las necesidades que se presenten y las realidades que emerjan de cada caso particular, siempre tomando en consideración que están supeditados a los acuerdos alcanzados por las partes antes y durante el desarrollo de los procedimientos. En efecto, lo dispuesto en la mencionada reglamentación replica las normas básicas del arbitraje internacional en las que el árbitro adquiere gran protagonismo y facultades de impulso de las actuaciones, lo que redunda en los criterios de efectividad, seguridad y celeridad que caracterizan esta clase de mecanismos alternativos.

Visto lo anterior, es posible afirmar que la configuración legal de la amigable composición resulta en gran medida favorable para que tanto las partes involucradas en los conflictos como las entidades privadas que se dedican a la prestación de estos servicios reglamenten los procedimientos ajustados a las necesidades de cada caso. Por su lado, las funciones de control, inspección y vigilancia atribuidas por ley al Ministerio de Justicia y del Derecho no han sido determinantes para que por medio de actuaciones administrativas se homogeneicen visiones exclusivas y excluyentes de lo que deben ser los procedimientos de amigable composición adelantados por los centros operadores de este mecanismo alternativo de solución de controversias. En tal sentido, los reglamentos modelo expedidos por el gobierno nacional han conservado su carácter de verdaderas guías para aquellos centros que deseen replicarlos y alinearse bajo

\footnotetext{
el procedimiento establecido por las partes se llenarán aplicando el Reglamento de Amigable Composición del Centro, y lo no previsto en el reglamento lo llenará el amigable componedor. Artículo 7.4. Funciones del amigable componedor. De conformidad con el presente reglamento, el amigable componedor tendrá $\emptyset$ todas las funciones necesarias para dar cumplimiento al encargo de solucionar el conflicto de las partes. Especialmente las siguientes: (...) 2. Dirigir el trámite de la amigable composición y tomar las decisiones que considere necesarias para el buen funcionamiento del trámite y la garantía de los principios rectores de este reglamento. Artículo 7.5. Principios. El presente reglamento se rige por los siguientes principios: 1. Autonomía de la voluntad privada: las partes pactarán y acudirán a este mecanismo de manera voluntaria en ejercicio de su libertad privada y, en ese sentido, podrán pactar, de común acuerdo la forma como se desarrollará y tramitará la amigable composición". Cámara de Comercio de Bogotá, Centro de Arbitraje y Conciliación, Reglamentos. Reglamento de amigable composición. Disponible en: http://www.centroarbitrajeconciliacion.com/Servicios/ Arbitraje/Reglamento-y-normatividad, http://www.centroarbitrajeconciliacion.com/content/ download/9245/122796/file/Reglamento\%20amigable $\% 20$ composici $\%$ C3\%B3n.pdf
} 
los parámetros sugeridos y en una menor medida, han representado imposiciones de fórmulas contractuales emanadas de una autoridad con pretensiones unificadoras.

\section{Perspectiva jurisprudencial}

La jurisprudencia colombiana sobre amigable composición, tanto en sede de jurisdicción constitucional como en ordinaria y contencioso administrativa, es bastante menos abundante que aquella que se ha proferido en relación con el arbitraje y otros mecanismos alternativos. Resulta posible identificar cuatro razones esenciales que explican esta situación:

En primer lugar, al no existir consagración expresa de la amigable composición en el texto constitucional, las demandas sobre exequibilidad de sus disposiciones son difícilmente promovibles, a diferencia de lo que sucede con el arbitraje, cuyos definitorios contemplados en el texto superior (carácter jurisdiccional, principio de habilitación etc.) constituyen referentes permanentemente cotejados con las normativas de rango inferior que lo reglamentan.

En segundo lugar, la normatividad que regula la materia es escasa e históricamente se ha limitado a un número reducido de artículos que configuran sus características y alcances. Por cuenta de esta particularidad, resulta materialmente limitada la procedencia de las acciones de constitucionalidad que se pueden ejercitar contra las normas que la desarrollan; esta situación es igualmente diversa en el caso del arbitraje, figura que en la actualidad cuenta con alrededor de ciento dieciséis (116) artículos que lo modelan.

En tercer lugar, incide el auge poco significativo de la figura de la amigable composición, en comparación con otros mecanismos como la conciliación y el arbitraje, lo que significa un limitado número de casos adelantados cada año al amparo de las instituciones prestadoras del servicio ${ }^{52}$. Esta premisa queda plasmada en

52 En efecto, ya hace algunos años, el tratadista ENRIQUE GAVIRIA-GUTIÉRREZ expresó acertadamente: "Pocos esquemas legales hay tan desconocidos como la amigable composición. Más aún: no se sabe bien si esta figura corresponde a un solo convenio o si únicamente se explica por la concurrencia de varios que se complementan; no faltará quien piense, además, que la composición no es un contrato sino un procedimiento para la solución de conflictos, e inclusive, como se verá, a veces se confunde con el arbitraje en conciencia; así ocurre, en efecto, con algunos países extranjeros. (...) En fin, no pocos le prestan muy escasa atención a la amigable composición y más bien pretenden relegarla a un cómodo olvido, pensando que, 
los siguientes gráficos que muestran un comparativo del número total de casos recibidos para resolver controversias en arbitraje y amigable composición entre 2010 y 2015 ante la Cámara de Comercio de Bogotá, el mayor operador nacional de estos mecanismos alternativos de solución de controversias.
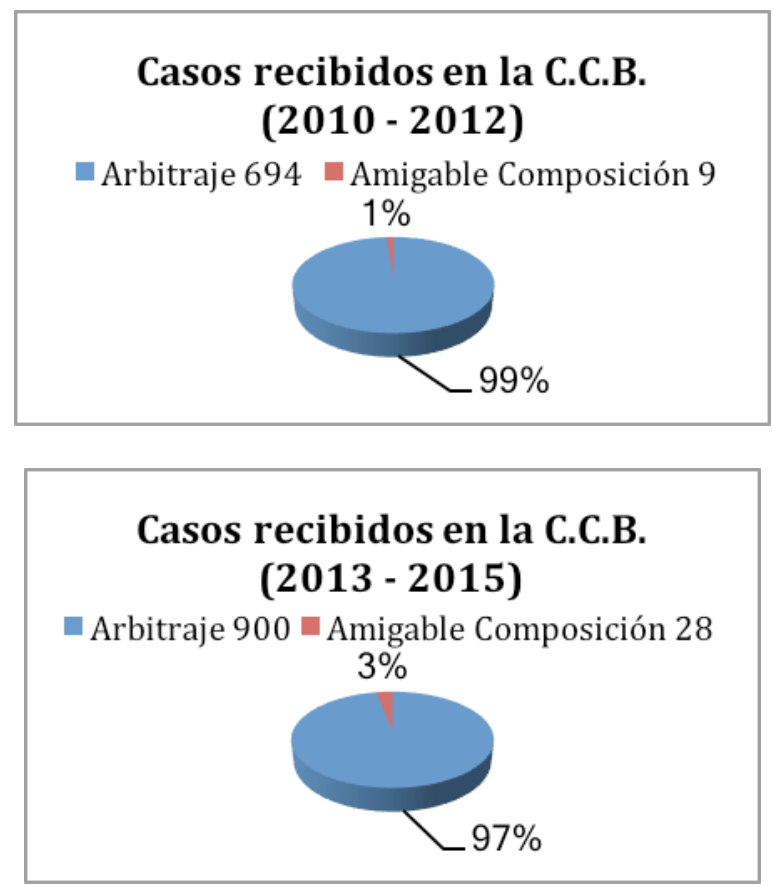

Fuente: elaboración propia con base en información obtenida directamente del Centro de Arbitraje y Conciliación de la Cámara de Comercio de Bogotá

Resulta evidente, entonces, que un número tan poco significativo de casos (un promedio de 6,16 por año, tan solo en ese centro de arbitraje) constituye un universo bastante restringido para dar lugar a eventuales intervenciones jurisdiccionales en las que se produzca jurisprudencia sobre el particular ${ }^{53}$.

si no se utiliza tanto como otras figuras alternas, alguna razón existirá para justificar ese estado de semiparalización que hoy la caracteriza”. ENRIQUE GAVIRIA-GUTIÉRREZ, Lecciones de derecho comercial (Diké, Medellín, 1987).

53 Información obtenida directamente del Centro de Arbitraje y Conciliación de la Cámara de Comercio de Bogotá. 
Por último, el carácter contractual y no jurisdiccional de la amigable composición también ha resultado determinante en la poca producción jurisprudencial existente sobre el particular, ya que los presupuestos de procedencia de las acciones de tutela para protegerse de las vías de hecho atribuibles a los jueces no les resultan aplicables a los amigables componedores. En igual sentido, la Corte Constitucional se pronunció sobre la improcedencia de estos mecanismos de protección de derechos en contra de los centros y los amigables componedores, dada su condición de particulares y el carácter privado de su actividad. No obstante lo anterior, el tribunal constitucional colombiano ha determinado en sendos pronunciamientos que la protección de derechos fundamentales es procedente para el caso de la amigable composición, no por la naturaleza de las funciones que estos operadores desarrollan ni por la aplicación de las reglas tradicionales de procedencia de la tutela contra particulares, sino por la posible ocurrencia de "perjuicios irremediables" o de la existencia de una "situación de indefensión" de las partes frente a los amigables componedores ${ }^{54}$.

Los pronunciamientos de la Corte Constitucional han contribuido a definir algunos aspectos trascendentales de la figura, incluyendo algunos que tocan con las posibles limitaciones a la autonomía de la voluntad contractual. En especial, llamamos la atención sobre aquellos parámetros que, en criterio de esta corporación, deben observar las partes y los amigables componedores a la hora de establecer los procedimientos a seguir.

En tal sentido, resulta de particular trascendencia un pronunciamiento en el que la Corte resolvió una controversia en la que estaban involucrados el Instituto Nacional de Vías, INVIAS, y el Consorcio Survial. En la mencionada disputa, la entidad estatal

54 Colombia, Corte Constitucional, Sentencia SU091-00, 2 de febrero de 2000, magistrado ponente Álvaro Tafur-Galvis. Disponible en: http://www.corteconstitucional.gov.co/relatoria/2000/ su091-00.htm. De la misma manera, la Corte ha señalado: "En el presente caso subyace una situación de indefensión, pues de adelantarse el trámite de la composición sin unas reglas claras y objetivas previamente conocidas por todos los intervinientes, no existiría ningún parámetro de control al ejercicio de las atribuciones del amigable componedor, lo que indiscutiblemente sometería al INVIAS, como al Consorcio Survial, a un estado de dependencia fáctico o circunstancial en relación con el amigable componedor, ya que al final de cuentas la resolución del conflicto dependería exclusivamente de los designios de dicho mandatario". Colombia, Corte Constitucional, Sentencia T-017-05, 20 de enero de 2005, magistrado ponente Rodrigo Escobar-Gil, Fundamentos jurídicos de la Corte, 20. Disponible en: http://www. corteconstitucional.gov.co/relatoria/2005/t-017-05.htm 
consideró vulnerados sus derechos fundamentales al debido proceso y a la defensa, por cuanto en la amigable composición a la cual se habían sometido las partes no existía ni legal ni reglamentariamente un procedimiento establecido para su realización. Argumentó la citada entidad que sus derechos fundamentales habían sido desconocidos pues no había tenido lugar un acuerdo previo por parte del INVIAS y el Consorcio Survial en relación con el procedimiento a seguir para resolver las controversias por medio de la amigable composición. En opinión de la accionante, el citado mecanismo de resolución de conflictos tiene como fundamento el acuerdo entre las partes y si este no existe en torno al procedimiento que antecede a su práctica, no es legítimo proceder a su desarrollo, hasta cuando se llegue a un consenso de tipo procesal. Por las razones antes mencionadas, el problema jurídico se concretó en si el Centro de Conciliación, Arbitraje y Amigable Composición de la Sociedad Colombiana de Ingenieros incurrió en una vulneración de los derechos fundamentales al debido proceso y a la defensa, al no declarar fracasada o fallida la instancia de la amigable composición entre las partes por no haberse estipulado ni directa ni indirectamente un procedimiento ${ }^{55}$.

En este caso, la Corte reafirmó que la amigable composición es una institución de derecho sustancial, más específicamente del derecho de los contratos, al igual que la transacción, que se diferencia del arbitraje y la conciliación en que estas últimas corresponden a instituciones procesales. En este sentido, reitera que los amigables componedores no ejercen función jurisdiccional mientras que los árbitros sí lo hacen, en virtud de lo establecido en la Carta Política. En lo que respecta al trámite, la alta corporación dispuso que la amigable composición tiene un carácter contractual, sin consecuencias procesales, por lo que se deja al criterio de las partes su configuración. Este mecanismo se materializa finalmente en un "convenio de composición" que es delegado en un tercero pero que no es una sentencia judicial.

En virtud de lo anterior, la Corte señaló que entre el amigable componedor y las partes surge un vínculo originado en un contrato

55 Colombia, Corte Constitucional, Sentencia T-017-05, 20 de enero de 2005, magistrado ponente Rodrigo Escobar-Gil. Disponible en: http://www.corteconstitucional.gov.co/ relatoria/2005/t-017-05.htm 
de mandato, por lo que las facultades del mandatario se enmarcan en lo establecido en el contrato de composición. En este orden de ideas, la amplitud de las actuaciones que adelante el amigable componedor dependerá de las restricciones o no que le fijen sus mandatarios. Realizadas las anteriores precisiones en las que se reafirmó la naturaleza contractual de la amigable composición, la Corte desligó completamente esta figura del ámbito procesal; en este sentido, ratificó que el compromiso suscrito entre las partes, por medio de la decisión del amigable componedor, no es susceptible de ningún recurso de tipo procesal, como efectivamente sí sucede con los laudos arbitrales. Por el contrario, sostiene que la manera de controvertir este acuerdo es mediante la demostración de su ineficacia como acto jurídico por falta de capacidad de las partes, ausencia de consentimiento, existencia viciada del mismo o presencia de objeto o causa ilícita.

Las conclusiones derivadas del profundo análisis que realiza la Corte sobre este mecanismo de solución de controversias apuntan a que en la amigable composición hay un amplio margen para la aplicación de la autonomía de la voluntad, en su condición de mecanismo eminentemente convencional. Por ello, dispone que esta figura no puede estar sometida a una estructura procedimental convencional ni le puede ser exigible el adelantamiento de un proceso como presupuesto de validez y eficacia pues sus alcances como institución de derecho sustancial resultan innegables. En tal sentido, en esa misma sentencia, la Corte afirma:

De suerte que, en ejercicio de la autonomía de la voluntad privada, les asiste el derecho a las partes de fijar libremente los límites, condiciones y requisitos que estimen convenientes en cuanto a la forma como ha de adelantarse, en cada caso, la amigable composición (negrillas añadidas) ${ }^{56}$.

Entonces, resulta evidente para la Corte que el carácter jurisdiccional o contractual de un mecanismo alternativo de solución de controversias tiene consecuencias en su estructura procedimental, pero especialmente en el alcance de las libertades individuales de las partes para delimitar y definir los aspectos relacionados con

56 Colombia, Corte Constitucional, Sentencia T-017-05, 20 de enero de 2005, magistrado ponente Rodrigo Escobar-Gil, Fundamentos jurídicos de la Corte, 13. Disponible en: http://www. corteconstitucional.gov.co/relatoria/2005/t-017-05.htm 
su organización y funcionamiento. En tal sentido, el hecho de que la amigable composición no forme parte de los mecanismos en los que el constituyente les atribuyó la facultad de administrar justicia de manera temporal a los particulares, excluyó de su esfera la aplicación del derecho procesal. En este orden de ideas, para la Corte, el contrato de mandato que subyace entre las partes y el amigable componedor le atribuye a este último las potestades para definir el procedimiento a seguir en caso de que las partes no lo hayan acordado, ni directa ni indirectamente mediante referencia a un reglamento de un centro, sin que para dicha labor le resulte necesario acogerse a los presupuestos del procedimiento civil.

En virtud de lo anterior, y tomando en consideración los innegables vínculos de la amigable composición con el contrato de mandato, la Corte acude al artículo 2160 del Código Civil para resaltar el deber del mandatario de obrar conforme a los "medios" con los cuales el mandante hubiese querido su realización. Lo anterior no resulta nada diferente al obrar de buena fe, de forma ecuánime y neutral, y asegurar la igualdad de armas para quienes concurren a resolver sus diferencias. En este punto, el pronunciamiento del alto tribunal establece unas condiciones al ejercicio de las funciones del amigable componedor en lo relativo a la definición del trámite cuando esta responsabilidad recae sobre él. En igual sentido, la sentencia cobija los reglamentos de los centros de arbitraje ante los que se promueva la solución de la diferencia. Estos presupuestos, si bien no someten a estos operadores a las formas del derecho procesal en toda su extensión, sí resultan llamativos por replicar esquemas tradicionales de los procesos civiles, pues disponen la necesidad de que se lleven a cabo tres etapas: 1) una audiencia de apertura, 2) una etapa de investigación y 3) una etapa de decisión ${ }^{57}$.

“(...) es indispensable que los centros especializados en el manejo de los mecanismos alternativos de resolución de conflictos, sometan el adelantamiento de los trámites de la amigable composición como mínimo a tres etapas. En primer lugar, a una audiencia de apertura, en donde se proclame la autoridad del amigable componedor, se fije el alcance y naturaleza de la disputa, se determine el tiempo de su duración y el de cada una de sus etapas y, además, se inste a las partes para presentar los elementos de juicio que pretendan hacer valer. En segundo término, una etapa de investigación, para identificar y estudiar el problema, examinar documentos, realizar entrevistas con terceros y las partes, y en general, todas las gestiones esenciales para que el amigable componedor se forme su propio juicio. Finalmente, la etapa de decisión, audiencia en la cual se presenta la solución a las partes debidamente firmada por el amigable componedor, y se explica su alcance jurídico" (itálicas añadidas). Colombia, Corte Constitucional, Sentencia T-017-05, 20 de enero de 2005, magistrado ponente Rodrigo 


\section{CONCLUSIONES}

La amigable composición fue concebida como una figura independiente del arbitraje, con escasa regulación legal y con un carácter eminentemente contractual, pese al hecho de que, en la práctica, el amigable componedor es un tercero que define con fuerza vinculante para las partes una controversia de libre disposición. No obstante tratarse de un esquema convencional para la solución de diferencias, el legislador y los entes gubernamentales como el Ministerio de Justicia y del Derecho han desarrollado algunos aspectos que tocan con su procedimiento sin que se pueda afirmar, de manera contundente, que sean regulaciones que signifiquen intromisiones sustanciales en el espacio volitivo de la autonomía privada.

Por otro lado, pese a tratarse de una figura que no tiene raigambre constitucional, la Corte Constitucional ha emitido pronunciamientos tendientes a la protección de los derechos fundamentales de las partes involucradas. En estos proveídos, el ente jurisdiccional no se ha pronunciado sobre el alcance de los derechos de las partes para definir los procedimientos que rigen sus trámites, pero ha impuesto una serie de parámetros de obligatorio cumplimiento para los amigables componedores cuando de ellos depende el establecimiento de las condiciones en que desarrollen su gestión. Así mismo, el alcance de esas decisiones toca la independencia de los centros de arbitraje y amigable composición en la medida en que condicionan la estructura de sus reglamentos a la existencia de una serie de etapas de apertura, investigación y decisión.

No obstante esto último, es posible afirmar que tanto la regulación legal y estatutaria de la amigable composición, como la jurisprudencia que se ha desatado alrededor de la figura han garantizado su carácter de mecanismo de solución de controversias de naturaleza eminentemente contractual. De esta manera, se han preservado las garantías individuales para que las partes puedan resolver sus diferencias de manera autónoma, tomando en consideración las particularidades de su conflicto y quedando ellas en completa libertad para definir los alcances del procedimiento, su estructura, sus tiempos y las funciones de los amigables compo-

Escobar-Gil, Fundamentos jurídicos de la Corte, 16. Disponible en: http://www.corteconstitucional.gov.co/relatoria/2005/t-017-05.htm 
nedores, de manera tal que el trámite responda a las necesidades y expectativas de efectividad, celeridad y eficacia que demanda el actual tráfico mercantil.

En virtud de lo anterior, varias reflexiones se pueden extraer del análisis de la figura de la amigable composición, pero resultan particularmente interesantes las proyecciones que se pueden derivar de ese análisis al caso del arbitraje doméstico en Colombia. En primer lugar: la amigable composición es un mecanismo de naturaleza eminentemente contractual en el que el tercero no solo precisa la forma de cumplimiento de un contrato o negocio jurídico particular, sino que puede determinar aspectos relacionados con su incumplimiento y responsabilidades derivadas; por su lado, el arbitraje es una expresión jurisdiccional, con profundas raíces en el campo procesal, en el que el árbitro también se pronuncia sobre aspectos de igual naturaleza derivados de una relación regularmente convencional. En segundo lugar, es viable afirmar que las diferencias más importantes entre las dos figuras se originan en la fórmula de consagración constitucional del arbitraje, lo que derivó en una aproximación diametralmente opuesta a la aplicabilidad de los principios de voluntariedad y de autonomía de la voluntad para cada figura.

Por consiguiente, es dable afirmar que el constituyente habría podido acoger una visión contractualista del arbitraje, como bien lo hizo el legislador con la amigable composición, mecanismo igualmente adjudicativo, caso en el cual los principios y libertades básicas que hoy resultan aplicables a la amigable composición serían igualmente extensibles al arbitraje doméstico, lo cual garantizaría la existencia de un mecanismo mucho más conforme con los designios que sobre la materia se destacan en el ámbito internacional y que nuestra misma normativa reconoce en el apartado III de la Ley 1563 de 2012 para esta clase de arbitraje. 


\section{BIBLIOGRAFÍA}

\section{Libros}

Berger, Klaus Peter \& Kessedjian, Catherine, Forum Internationale, The New German Arbitration Law in International Perspective: The Draft Convention Proposed by The Hague Conference on Private International Law (Kluwer International, Dordrecht, 2000).

Born, Gary B., International Arbitration: Cases and Materials (Aspen Casebook Series, Wolters Kluwer Law International, New York, 2015).

Carnelutti, Francesco, Derecho procesal civil y penal (Ediciones Jurídicas, Europa América, Buenos Aires, 1971).

Gaviria-Gutiérrez, Enrique, Lecciones de derecho comercial (Diké, Medellín, 1987).

Gil-Echeverry, Jorge Hernán, La conciliación extrajudicial y la amigable composición (Editorial Temis, Bogotá, 2011).

PARICIO, JAvier, Los arbitrajes privados en la Roma Clásica (Marcial Pons Ediciones Jurídicas y Sociales S.A., Madrid, 2014).

\section{Colaboración en obras colectivas}

Mantilla-Serrano, Fernando, La autonomía del derecho del arbitraje internacional: ¿hacia un arbitraje realmente autónomo?, en Arbitraje internacional - Tensiones actuales, 207-242 (Fernando Mantilla-Serrano, ed., Legis, Bogotá, 2007).

Osorio-Hernández, Mario Ricardo, Amigable composición y arbitraje en equidad: pasado presente y futuro de dos engendros colombianos, en Ensayos arbitrales, 13-26 (Cámara de Comercio de Bogotá, Kimpres, Bogotá, 2010).

\section{Revistas}

Fernández-Rozas, José Carlos, Arbitraje y jurisdicción: una interacción necesaria para la realización de la justicia, 13 Derecho Privado y Constitución, Centro de Estudios Políticos y Constitucionales, CEPC, Madrid, 19, 55-91 (2005). Disponible en: http://eprints.ucm.es/6573/1/ARBITRAJE_Y_JURISDICCION.pdf

Rey-Vallejo, Pablo, La autonomía del arbitraje doméstico desde la perspectiva constitucional en Colombia y puntuales análisis de derecho comparado latinoamericano, 34 Revista de Derecho Público, Universidad de los Andes, 1-37 (2015). Disponible en: https://derechopublico.uniandes.edu.co/components/ com_revista/archivos/derechopub/pub496.pdf

\section{Normatividad internacional}

Alemania, Código Procesal Civil, Zivilprozessordnung, ZPO, 30 de enero de 1877. 
Comisión de las Naciones Unidas para el Derecho Mercantil Internacional, CNUDMI, Ley Modelo sobre Arbitraje Comercial, 1985, con las enmiendas aprobadas en 2006. Disponible en: https://www.uncitral.org/pdf/spanish/texts/arbitration/ ml-arb/07-87001_Ebook.pdf

España, Constitución española, 27 de diciembre, 311 Boletín Oficial del Estado, BOE, 29 de diciembre de 1998. Disponible en: https://www.boe.es/diario_boe/txt. php?id=BOE-A-1978-31229

España, Ley de Arbitraje, Ley 60/2003, 23 de diciembre, 309 Boletín Oficial del Estado, $B O E, 26$ de diciembre de 2003. Disponible en: https://www.boe.es/buscar/act. php?id=BOE-A-2003-23646

Francia, Código de Procedimiento Civil, Code de Procédure Civile, CPC, 14 de abril de 1806. Disponible en: https://archive.org/details/codedeprocdurec00frangoog

Italia, Regio decreto-legge 262, 16 marzo 1942, Approvazione del testo del Codice Civile. Disponible en: http://www.jus.unitn.it/cardozo/obiter_dictum/codciv/Codciv.htm

Italia, Regio decreto-legge 1443, 28 ottobre 1940, Codice di Procedura Civile. Disponible en: http://www.normattiva.it/uri-res/N2Ls?urn:nir:stato:decreto.regio:1940-10$28 ; 1443$ !vig $=$

\section{Normatividad colombiana}

Colombia, Constitución Política, promulgada el 7 de julio de 1991, versión corregida, 116 Gaceta Constitucional, 20 de julio de 1991. Disponible en: http://www. secretariasenado.gov.co/senado/basedoc/constitucion_politica_1991.html

Colombia, Decreto 1400 de 1970, por el cual se expide el Código de Procedimiento Civil, 33.150 Diario Oficial, 21 de septiembre de 1970. Disponible en: http://www. alcaldiabogota.gov.co/sisjur/normas/Norma1.jsp?i=6923

Colombia, Decreto 410 de 1971, por el cual se expide el Código de Comercio, 33.339 Diario Oficial, 16 de junio de 1971. Disponible en: http://www.alcaldiabogota. gov.co/sisjur/normas/Normal.jsp?i=41102

Colombia, Decreto 2279 de 1989, por el cual se implementan sistemas de solución de conflictos entre particulares y se dictan otras disposiciones, 39.012 Diario Oficial, 7 de octubre de 1989. Disponible en: http://www.icbf.gov.co/cargues/avance/docs/ decreto_2279_1989.htm

Colombia, Ley 105 de 1931, sobre organización judicial y procedimiento civil, 21.823 Diario Oficial, 24 de octubre de 1931. Disponible en: http://www.icbf.gov.co/ cargues/avance/docs/ley_0105_1931.htm

Colombia, Ley 2 de 1938, por la cual se da validez a la cláusula compromisoria, 23.727 Diario Oficial, 12 de marzo de 1938. Disponible en: https://www.cancilleria.gov. co/sites/default/files/Normograma/docs/ley_0002_1938.htm

Colombia, Ley 23 de 1991, por medio de la cual se crean mecanismos para descongestionar los despachos judiciales, y se dictan otras disposiciones, 39.752 Diario Oficial, 21 de marzo de 1991. Disponible en: https://www.minjusticia.gov.co/portals/0/ MJD/docs/ley_0023_1991.htm 
Colombia, Ley 446 de 1998, por la cual se adoptan como legislación permanente algunas normas del Decreto 2651 de 1991, se modifican algunas del Código de Procedimiento Civil, se derogan otras de la Ley 23 de 1991 y del Decreto 2279 de 1989, se modifican y expiden normas del Código Contencioso Administrativo y se dictan otras disposiciones sobre descongestión, eficiencia y acceso a la justicia, 43.335 Diario Oficial, 8 de julio de 1998. Disponible en: http://www. secretariasenado.gov.co/senado/basedoc/ley_0446_1998.html

Colombia, Ley 1563 de 2012, por medio de la cual se expide el Estatuto de Arbitraje Nacional e Internacional y se dictan otras disposiciones, 48.489 Diario Oficial, 12 de julio de 2012. Disponible en: http://www.secretariasenado.gov.co/senado/ basedoc/ley_1563_2012.html

Colombia, Ley 1564 de 2012, por medio de la cual se expide el Código General del Proceso y se dictan otras disposiciones, 48.489 Diario Oficial, 12 de julio de 2012. Disponible en: http://www.secretariasenado.gov.co/senado/basedoc/ ley_1564_2012.html

\section{Reglamentos}

Cámara de Comercio de Bogotá, Centro de Arbitraje y Conciliación, Reglamentos. Reglamento de amigable composición. Disponible en: http://www.centroarbitraje conciliacion.com/Servicios/Arbitraje/Reglamento-y-normatividad, http://www. centroarbitrajeconciliacion.com/content/download/9245/122796/file/ Reglamento $\% 20$ amigable $\% 20$ composici $\% \mathrm{C} 3 \% \mathrm{~B} 3 \mathrm{n}$.pdf

\section{Proyectos de ley}

Informe de ponencia para primer debate al Proyecto de Ley 18 de 2011 Senado, por medio de la cual se expide el Estatuto de Arbitraje Nacional e Internacional y se dictan otras disposiciones, 817 Gaceta del Congreso, 2 de noviembre de 2011. Disponible en: http://www.imprenta.gov.co/gacetap/gaceta.nivel_3

Informe de ponencia para primer debate al Proyecto de Ley 176 de 2011 Cámara, 18 de 2011, Senado, por medio de la cual se expide el Estatuto de Arbitraje Nacional e Internacional y se dictan otras disposiciones, 108 Gaceta del Congreso, 27 de marzo de 2012. Disponible en: http://www.imprenta.gov.co/gacetap/gaceta. nivel_3

Informe de ponencia segundo debate proyecto de ley 176 de 2011 Cámara, 18 de 2011 Senado, ¿Ley de Arbitraje Nacional e Internacional?, 321 Gaceta del Congreso, 6 de junio de 2012. Disponible en: http://www.imprenta.gov.co/gacetap/gaceta. nivel_3

\section{Jurisprudencia internacional}

España, Tribunal Constitucional, Sentencia 176/1996, 11 de noviembre, 303 Boletín Oficial del Estado, BOE, 17 de diciembre de 1996. Disponible en: http:// hj.tribunalconstitucional.es/es/Resolucion/Show/3228 


\section{Jurisprudencia colombiana}

Colombia, Corte Constitucional, Sentencia C-037-96, 5 de febrero de 1996, magistrado ponente Vladimiro Naranjo-Mesa. Disponible en: http://www. corteconstitucional.gov.co/relatoria/1996/C-037-96.htm

Colombia, Corte Constitucional, Sentencia C-893-01, 22 de agosto de 2001, magistrada ponente Clara Inés Vargas-Hernández. Disponible en: http://www. corteconstitucional.gov.co/relatoria/2001/c-893-01.htm

Colombia, Corte Constitucional, Sentencia C-1195-01, 15 de noviembre de 2001, magistrados ponentes Manuel José Cepeda-Espinosa y Marco Gerardo Monroy-Cabra. Disponible en: http://www.corteconstitucional.gov.co/ relatoria/2001/c-1195-01.htm

Colombia, Corte Constitucional, Sentencia C-014-10, 20 de enero de 2010, magistrado ponente Mauricio González-Cuervo. Disponible en: http://www. corteconstitucional.gov.co/relatoria/2010/c-014-10.htm

Colombia, Corte Constitucional, Sentencia C-222-13, 17 de abril de 2013, magistrada ponente María Victoria Calle-Correa. Disponible en: http://www. corteconstitucional.gov.co/relatoria/2013/c-222-13.htm

Colombia, Corte Constitucional, Sentencia SU091-00, 2 de febrero de 2000, magistrado ponente Álvaro Tafur-Galvis. Disponible en: http://www.corteconstitucional. gov.co/relatoria/2000/su091-00.htm

Colombia, Corte Constitucional, Sentencia T-017-05, 20 de enero de 2005, magistrado ponente Rodrigo Escobar-Gil. Disponible en: http://www.corteconstitucional. gov.co/relatoria/2005/t-017-05.htm

\section{Recursos electrónicos}

Programa Nacional de Conciliación, Modelo de Reglamento Interno para Centros de Conciliación Arbitraje y Amigable Composición. Disponible en: http:// conciliacion.gov.co/portal/documentos 
